\title{
FUNDAMENTAÇÃO TEÓRICA - A ESCOLHA DAS ABORDAGENS
}

Neste texto, as bases teóricas adotadas são oriundas da psicodinâmica do trabalho (PDT) e da ergonomia da atividade. A proposta não é de esgotar o tema, mas sobretudo, a partir de alguns conceitos - chave, desenvolver as ideias citadas anteriormente com relação ao protagonismo no e do trabalho. Dentre esses conceitos, em primeiro lugar, damos ênfase, à discrepância entre o real e o prescrito, tema clássico na ergonomia da atividade, mas que permanece bastante obscuro aos olhos das teorias organizacionais clássicas. O propósito não é o de enumerar os trabalhos que nos trazem esta evidência empírica, algo será tratado na apresentação de resultados de pesquisas feitas por mim e por colegas que trabalham em cooperação comigo, mas o de reafirmar que a atividade desenvolvida por quaisquer trabalhadores, não corresponde exatamente àquilo que foi previsto ao se projetar uma tarefa. Trata-se de duas ontologias diferentes, a tarefa com sentido prescritivo e normativo e a atividade, pertencente ao mundo do vivido, da experiência de cada um, do uso do corpo para obter um determinado resultado. A tarefa, como diz Clot (I995), também resulta da atividade de alguém, isto é, daqueles que, de alguma maneira a prescreveram. Duas ontologias diferentes, portanto, dois universos diferentes que, constituem o mundo da produção. Não há produção sem que se projete, de alguma maneira, as tarefas e o seu universo, assim como não há produção sem a atividade daqueles que, em diálogo com a tarefa prescrita, desenvolvem suas atividades.

Sem um trabalho pessoal, de cada um, para interpretar a tarefa em confronto com mundo real e com a sua psique, que, sempre se apresentam de formas diversas para os mais diferentes sujeitos, não se pode agir para produzir. 
Este trabalho pessoal requer uma experimentação, um contato com o mundo e, como o real não corresponde ao prescrito, é preciso construir o fazer, é preciso reinventar a tarefa para que a produção saia a contento, na perspectiva das exigências da qualidade e da produtividade esperadas, é nesse espaço que protagonismo se constitui, a proposta é que seja um conceito a ser integrado nas ciências do trabalho e da produção.

Todavia, a busca de construir uma atividade que responda de modo adequado às exigências externas, não é algo que possa ser considerado simples, banal. Em primeiro lugar, o real resiste à vontade dos sujeitos (DEJOURS, $20 \mathrm{I} 2 \mathrm{~b}$ ), assim ao querer transformar a matéria, o trabalhador encontra uma série de dificuldades que o obrigam a experimentar, a buscar novas soluções, novos caminhos, enfim algo que lhe permita chegar a um resultado satisfatório. O mesmo vale para alguém que, ao tratar diferentes tipos de informação para agir, não as encontra de modo a fazer como havia previsto anteriormente. As mesmas questões se colocam para o caso dos trabalhos relacionais, onde a vontade do outro sempre está presente e, ela também não corresponde à da pessoa que está desenvolvendo a sua atividade em uma relação de serviço. Em suma, trabalhar significa, construir uma ação, significa zelar para que se obtenha os melhores resultados possíveis, significa transgredir as normas prescritas e criar outras que estejam mais em conformidade com a resistência do real.

Isto nos leva a considerar que não basta tratar a questão da produção sob a ótica da qualidade e da produtividade proposta pelas escolas de organização e de administração clássicas. Em primeira instância, reforçando a ideia do protagonismo, estaria a perspectiva da profissão, do métier. Trata-se de uma questão da tradição, de uma certa cultura, com relação ao bem fazer e ao fazer o bem, isto é, uma maneira de agir no mundo modulada por questões deônticas, isto é, pelas regras da profissão e da relação desta com a sociedade, de um modo mais amplo.

Um dos legados da psicodinâmica do trabalho, aliás já presente nos primeiros trabalhos propostos pela psicopatologia do trabalho, é o conceito das defesas psíquicas (Dejours, 2008), erigidas de modo individual e coletivo para fazer frente a um real que, de alguma maneira ameaça a integridade do sujeito, seja ela uma ameaça física representando um risco de doença ou de acidente ou ainda uma ameaça mais simbólica que representaria um risco mais direcionado para a esfera da economia psíquica. Assim, se confrontar com o real significa também recear, ter medo de que algo nos traga perigo, seja porque podemos adoecer, nos ferirmos, morrermos, seja porque receamos não obter sucesso naquilo que estamos fazendo uma vez que devemos atingir certos objetivos que ainda não sabemos se somos capazes. Esta vivência, sempre mobiliza diferentes mecanismos de defesa, que podem se apresentar como formas de negação, seja 
através de comportamentos inusitados, seja por estratégias que dificultem um pensamento mais reflexivo e elaborado (DEJOURS, 20 I I b). O desenvolvimento de um certo ativismo profissional onde o sujeito faz mais e mais, sem que se dê conta desses processos de auto-aceleração é um dos fenômenos aí descritos. Esses processos estão fortemente relacionados com a luta contra o medo, contra o tédio, contra a emergência de um desejo mais profundo de fazer de outras maneiras e de viver outras situações de trabalho.

Nesses primeiros parágrafos relativos à discussão teórica já se colocam alguns desafios significativos. Ao tratar daquilo que foi proposto até o presente, fica evidente que há problemas de fundo relacionadas com o posicionamento das duas disciplinas citadas, a ergonomia da atividade e a psicodinâmica do trabalho, tanto no que diz respeito aos conceitos e práticas por elas desenvolvidos, como em relação ao seu pertencimento em termos epistemológicos. Assim, há uma necessidade de diálogo entre as duas correntes e, destas com outras disciplinas que, de alguma maneira fazem parte do seu corpo de conhecimento e, também aquelas que com elas debatem. 


\subsection{AS CONTRIBUIC̣ÕES DA ERGONOMIA}

Uma das questões fundamentais que pautou o desenvolvimento da ergonomia no século XX, utilizando uma discussão já feita sobre a obra de Alain Wisner (SZNELWAR, 2006), está justamente no reconhecimento da importância do trabalho para a produção tendo em vista a inteligência do trabalhador para dar conta das mais variadas situações de produção. A partir da constatação de que as prescrições feitas em uma tarefa, não podem ser simplesmente cumpridas para que os objetivos da produção sejam alcançados, fica bastante evidente que o trabalho é protagonista da produção. Isto só é possível devido ao engajamento dos trabalhadores e da sua contribuição inteligente para que se possa dar conta da variabilidade e dos eventos existentes em qualquer sistema de produção.

Um outro aspecto fundamental da ergonomia está relacionado com o largo espectro de contribuições de diferentes disciplinas para o seu desenvolvimento, se pensarmos que, na sua base temos a fisiologia e a psicologia cognitiva, não há como desconsiderar a importância da antropologia, da sociologia, da física, entre outras. Isto faz, como dizia Wisner (I993b), que a possamos considerar como uma arte, da mesma maneira como consideramos outras profissões, como a do engenheiro e a do médico. Aliás a ergonomia, além das contribuições que obteve de diferentes áreas do conhecimento, também contribuiu para o seu desenvolvimento. Aquilo que acontece na realidade da produção, ao ser evidenciado por uma análise da atividade coloca em questão as disciplinas de base, seja em seus métodos, nos resultados e nas abordagens para que estes possam responder às questões colocadas pelo real que difere sempre daquilo que foi pensado nos laboratórios ou em estudos desenvolvidos em outras situações que não as da produção. Podemos considerar então, que a ergonomia contribui e pode contribuir com várias áreas do conhecimento e com várias profissões, sobretudo porque se trata de contribuir para "engenheirar” um sistema de produção.

No âmbito do desenvolvimento da ergonomia, em um primeiro momento, a sua inserção em relação aos diferentes campos de conhecimento pode ser considerada como do mais puro pragmatismo, a questão em evidência era justamente a de resolver problemas de ordem prática, como foi o caso, dos primórdios da ergonomia moderna, na busca de resolver problemas relacionados às condições para se conduzir aviões de guerra durante a II Grande Guerra (I939-I945). Assim, ainda ao nos referirmos à obra de Wisner (I966, I99I), não vamos encontrar um aprofundamento maior quanto a uma reflexão epistemológica sobre a ergonomia, este tipo de reflexão pode ser encontrada no livro organizado por Daniellou (2004) onde vários autores contribuíram para uma reflexão mais teórica do que seria a ergonomia, sobretudo a ergonomia da atividade. Assim, vários autores ligados à corrente da ergonomia da atividade tinham uma 
evidente preocupação na busca de resolver os problemas colocados por diferentes atores sociais para resolver problemas de saúde, de acidentes, de qualidade e de produtividade, sejam eles da direção das empresas, dos sindicatos ou do Estado (WISNER, I995a). Como uma referência a contribuições teóricas na ergonomia feita por colegas contemporâneos a eles, podemos citar as de Montmollin (I 98 I) quando este autor discute as questões do taylorismo e as de Cazamian (1987) quando este propõe os conceitos relacionados ao que denominou de Ecologia Humana.

Mesmo sem ter desenvolvido, em grande parte de sua carreira, um trabalho de teorização sobre a epistemologia da ergonomia, que seria o de se colocar em uma posição meta com relação à ergonomia, a atuação de Wisner, de seus colegas e alunos no laboratório de ergonomia do Conservatoire National des Arts et Métiers (CNAM), em Paris, França, em muito contribuiu para que esta pudesse ser feita. Não temos como confirmar, mas esta pode ser considerada como a de alguém que estava construindo um campo, no âmbito da ergonomia da atividade e da antropotecnologia, baseado em um amplo leque de conhecimentos. Ele sobretudo lançou as bases para que este tipo de discussão fosse feita. A partir da prática, foram traçados os caminhos para o desenvolvimento de teorias. A sua trajetória mostra uma grande coerência e uma linha de conduta, exemplares. Ao analisarmos a sua postura e dos profissionais e pesquisadores que com ele colaboraram ou se inspiraram para agir no mundo do trabalho, é possível considerar que, mesmo ao não haver, no início uma obra para entender a ergonomia com relação a uma reflexão epistemológica, havia uma constante preocupação com seus fundamentos, como a da adaptação do trabalho às características humanas, mesmo que aparentemente, isto possa parecer muito amplo e fluido.

Convém reforçar a ideia que os projetos no laboratório do CNAM, quase sempre, estiveram atrelados a um projeto de pesquisa, de onde saíram várias teses de doutoramento, a produção de material científico e também material de vulgarização que contribuíram para o seu desenvolvimento. Dentre esses trabalhos, também é importante citar a contribuição para se constituir a ergonomia como um campo em diferentes países, inclusive no Brasil, onde a sua obra influenciou a construção do campo, qualificando pesquisadores e professores para atuarem na capacitação de profissionais e na transformação das situações de trabalho. Sua obra, foi em grande parte, resultante de uma postura militante em oposição às profundas desigualdades presentes no mundo da produção e ao desprezo com relação ao outro, sobretudo por serem desconsideradas a inteligência e a cultura dos trabalhadores e dos povos (WISNER, I993a). Este desprezo refletiria a existência de uma certa arrogância relacionada com a divisão do poder nas empresas que negligenciaria tanto as capacidades como os limites de todos que trabalhavam. (WISNER, I993 $b$ ). 
Convém lembrar que o posicionamento da ergonomia da atividade ao reconhecer a importância da inteligência do trabalhar era contra hegemônico, uma vez que, em grande parte do século XX, o pensamento científico ainda sofria grandes influências das ideias mais conservadoras, como foi o caso da influência do behaviorismo, uma das correntes da psicologia, que foi e ainda é, de certa forma, amplamente utilizada no mundo da produção.

Ao se posicionar na contra corrente do pensamento hegemônico em diferentes áreas, como a da administração, onde os pensamentos tayloristas e fordistas eram amplamente disseminados, abre-se uma discussão política, entendida como a possibilidade de se colocar no espaço público para defender uma posição, para que um tipo de pensamento possa ser entendido e que, sobretudo se desencadeiem processos de transformação da sociedade, de evolução da cultura. Enfim, agir no mundo, seja lá qual posicionamento é defendido pelo protagonista, é fazer política, mesmo que isto não seja uma postura como profissional da política ou de um partido. O ser humano, tanto na sua ação como na sua omissão (que pode ser considerada como uma forma de ação) é um ser político. 


\subsubsection{Algo sobre a evolução da ergonomia}

Mesmo ao buscar o desenvolvimento de estudos em situações reais de trabalho, a ergonomia da atividade não nega peremptoriamente o que pode ser feito em situações experimentais, típicas do estudos desenvolvidos em laboratórios. Todavia, mesmo que, parte dos estudos possam ser feitos em situações como estas, a relação com uma determinada realidade, tanto para o desenvolvimento de um produto, como para o de uma determinada situação de trabalho, a necessidade de se instaurar um processo iterativo é de primeira ordem. Este posicionamento aproxima muito a ergonomia das artes da engenharia, da arquitetura e do design.

Assim, podemos situar também uma certa maneira de atuar em ergonomia desenvolvida por Wisner, na sua busca inicial em melhorar um determinado produto, como o automóvel, quando trabalhou na indústria visando desenvolver melhorar o conforto para a condição do motorista e, baseado em conceitos da biomecânica e da fisiologia. Nesses estudos ele propôs alterações significativas no projeto partindo da busca de conhecimento em diferentes áreas, de experimentações em laboratório, e o de se basear nas situações de uso, visando um determinado objetivo, o de adaptar os objetos e as situações aos seres humanos. Assim ele propôs a incorporação de conceitos como o de massas suspensas para compreender a questão da transmissão de vibrações ao corpo humano através da suspensão e dos assentos dos veículos. Suas preocupações incluíram também a questão da relação entre acidentes e a queda na vigilância dos condutores, incorporando assim conhecimentos de fisiologia para projetos de engenharia do produto (WISNER, I992).

Apesar da importância da ergonomia do produto e todas as contribuições que ela trouxe e traz para que os mais diferentes artefatos sejam mais adaptados à fisiologia e à cognição humana, facilitando o papel dos protagonistas, a parte preponderante e mais significativa da obra deste autor diz respeito ao trabalho. As consequências do trabalho para o ser humano podem ser muito nefastas, ao considerarmos ainda a quantidade de pessoas mutiladas, doentes e, também, as mortes que estão relacionadas a acidentes e a doenças ligadas ao trabalho. Para as pessoas que tiveram algum tipo de sequela, tanto de ordem física como psíquica, o estigma é algo que se agrega à sua vida. Esses trabalhadores carregam, o fato de terem tido algo que os diferencia, que os torna não iguais.

Este posicionamento, sempre político, no qual o trabalho deve ser um meio para o indivíduo se desenvolver, se construir enquanto sujeito e para construir a sua saúde, o seu protagonismo, pode ser considerado como o grande impulsionador das ações em ergonomia e, também na psicodinâmica do trabalho.

A leitura de alguns conceitos mais tradicionais da ergonomia, como o de "carga de trabalho" mostra como esta disciplina esteve também influenciada 
por conceitos positivistas, uma vez que a busca de algo de mensurável, de palpável, de concreto que pudesse servir de parâmetro para a aplicação no mundo real faz parte de um posicionamento pragmático. Todavia, a mensuração, a partir de parâmetros sobretudo fisiológicos sempre esbarra na questão de que, aquilo que se consegue medir com relação a um fenômeno tão complicado, como o das atividades humanas são feitas a partir de modelos reducionistas. Isto coloca uma tensão interessante para o campo da ergonomia, o de como utilizar certas referências, sabendo que elas são parciais, que não explicam o que de fato ocorre, mas que podem ser úteis, se usadas com parcimônia.

Grande parte dos estudos em ergonomia evidenciam mais as consequências de uma possível "sobrecarga de trabalho" do que qualquer outra coisa. Isto nos aproxima do risco de sempre usarmos parâmetros que são inadaptados à maioria da população, sobretudo se não considerarmos que há uma significativa dispersão nas características de uma população, sejam elas por questões genéticas ou fenotípicas. Não se pode reduzir um parâmetro relacionado a uma população a uma determinada média; se quisermos, de fato, atuar em ergonomia, é fundamental que se considere os extremos em uma dispersão normal quando se trata de características humanas, ainda mais se quisermos desenvolver uma sociedade de inclusão e não de exclusão das pessoas.

Adotar conceitos como o de carga ou sobrecarga de trabalho como uma referência, só faz sentido se considerarmos uma questão fundamental, o da diversidade existente no humano, fato que complica bastante a discussão do que seria aceitável em determinada situação de trabalho. Não é à toa que os conceitos clássicos, adotados nas empresas, baseados no taylorismo e no fordismo, permitiam aos responsáveis pelos projetos e pela gestão, buscar homogeneizar as populações de trabalhadores no que diz respeito às suas características de porte físico, de sexo e, mesmo das capacidades intelectuais, uma tentativa de construir um ser humano médio, como se fosse um filme de ficção.

Isto não significa que haja, em princípio, uma malevolência nas propostas desenvolvidas nos sistemas de produção. O que há é resultado de um certo desenvolvimento técnico, econômico e social. Mas para reforçar a importância do posicionamento político, se essas questões não forem debatidas e não houver atores sociais com força para que não se defina os sistemas de produção a partir de um pensamento único, há sempre o risco de que estes sejam definidos com parâmetros que considerem os trabalhadores, seja qual for o seu nível hierárquico, como mais uma "peça” que pode, como maior ou menor dificuldade, ser trocada. Este ponto de vista é oposto ao posicionamento do protagonismo, onde cada qual se insere no sistema de produção como um sujeito, como alguém que tem uma história singular, como alguém que deseja realizar algo e que faz parte de um determinado contexto cultural, histórico e geográfico. 
Conciliar questões econômicas tais como o ponto de vista que coloca em evidência o sujeito em um determinado sistema de produção é um desafio que deve ser considerado e que deve fazer parte das preocupações dos atores sociais envolvidos com a produção. Ainda mais hoje em dia, quando as questões sobre confiabilidade dos sistemas, desenvolvimento sustentável e a divisão internacional do trabalho estão na ordem do dia. O desafio de evitar que o sujeito seja reificado (HONNETH, 2007) sempre se coloca na perspectiva da ergonomia e da psicodinâmica do trabalho.

Wisner (I97I/I995b) propunha que, para evitar perdas no sentido da economia, fossem consideradas de outro modo as questões humanas nos projetos das máquinas e ferramentas, assim como a dos sistemas de produção, de uma maneira mais ampla. Se considerarmos o que há de evidências com relação às perdas por causas de projetos pouco adaptados ou adaptáveis às características humanas, provavelmente essas mudanças seriam mais rápidas em nossas sociedades. Todavia, a contabilidade das empresas, dificilmente considera o que há de externalidades, tanto positivas quanto negativas com relação ao seu modo de produzir (TERTRE, HUBAULT, 2008). Se nos ativermos aos custos sociais dos acidentes de trabalho, das perdas da capacidade de trabalhar e, sobretudo o da subutilização das capacidades criativas das pessoas nos sistemas de produção, podemos ter uma ideia que há muito o que ser feito com relação aos benefícios econômicos do trabalho para a produção. Com relação ao valor do trabalho, em uma determinada situação, na Universidade de Campinas, Wisner, ao responder a uma questão, explicitou que o não reconhecimento da inteligência do trabalhador é um fato sobretudo porque ao reconhece-la, isto, de alguma forma, teria que se reverter em melhorias de salário.

Ao tratar de diferentes aspectos da atividade humana no trabalho, a ergonomia se constitui em um diálogo constante com outras áreas do conhecimento, como por exemplo, a toxicologia, a epidemiologia e a higiene do trabalho. Todavia, ao considerarmos a atividade de trabalho, fica evidente que a simples aplicação de conhecimentos oriundos dessas áreas não é suficiente, pois, no mais das vezes, esses são baseados em estudos em laboratório ou ainda, são fruto do conhecimento baseado na patologia. Construir um campo baseado na saúde e não na doença, guardando o trabalho como lócus privilegiado para a construção da saúde não é nada simples (DEJOURS, I985). Não basta considerar limites que poderiam ser tolerados quando da exposição a um determinado agente agressivo, há que se buscar soluções para que não ocorra a exposição e isto pode ser feito, considerando-se o conhecimento sobre as atividades de trabalho. $\mathrm{O}$ papel da ergonomia não seria o de definir qual é o nível aceitável de exposição em determinado contexto, uma vez que há outras questões em jogo, e que isolar um agente de risco do contexto de trabalho sem considerar outros aspectos, é 
uma distorção da realidade. A sua contribuição está justamente na compreensão $\mathrm{da}$ atividade e seus determinantes para poder transformar as situações de trabalho (SZNELWAR, I992, 2007).

O conhecimento da atividade de trabalho nos induz a evitar um ponto de vista linear baseado numa relação de causa e efeito pois estaríamos sempre buscando evidenciar as consequências, em primeiro lugar, para depois agir. Como pode ser evidenciado pela epidemiologia no que diz respeito à grande maioria das patologias relacionadas ao trabalho é um posicionamento perigoso, uma vez que, estas se instalam progressivamente e, ao serem detectadas, pode-se considerar que já é tarde, sobretudo se pensarmos no risco da ocorrência de sequelas. O objetivo em ergonomia e em outras disciplinas relacionadas à saúde do trabalhador é tratar de prevenção, ou melhor, de sua promoção. $\mathrm{O}$ conhecimento da atividade de trabalho não nos leva a propor soluções simples, como as de eliminar um agente agressivo, o que muitas vezes é muito complicado, mas de, a partir do que fazem efetivamente os trabalhadores, mudar as máquinas, os processos, a organização e os procedimentos do trabalho para evitar que haja exposição. Certos agentes, considerados como nocivos, são também fonte de informação necessária para o trabalho, portanto, ao reduzir-se a sua presença ou até elimina-la, é importante que que o trabalhador não perca a informação, útil para produzir e para garantir a sua segurança e a das instalações. Não se trata, portanto, de resolver um problema e criar um outro, assim o conhecimento das atividades de trabalho em suas múltiplas facetas, que sirva como situações de referência para projetos (DANIELLOU, 2006) pode ser muito útil. 


\subsubsection{Um diálogo com a Teoria da Complexidade}

Ao relacionar diferentes variáveis no âmbito do desenvolvimento da análise ergonômica do trabalho, onde se busca compreender o que está em jogo naquela situação, pode-se afirmar que em seu bojo, há uma similaridade com alguns pontos de vista da Teoria da Complexidade. Assim ao se evidenciar o emaranhado de relações entre as variáveis constituintes da atividade de trabalho é possível entender os diferentes fenômenos que dela emergem, sob uma ótica muito distinta das visões tradicionais da ciência, sobretudo aquelas fundadas em preceitos simplificadores da realidade. Assim, uma questão central para a ergonomia da atividade, que é o de compreender o que se passa na realidade, em consonância com as intenções dos sujeitos, pode ser discutida sob o ponto de vista da Teoria da Complexidade (MORIN, I990).

A questão da complexidade também é tratada por outros tipos de abordagem diferentes da proposta por Morin, mesmo que, em certos aspectos possamos encontrar pontos em comum. Por exemplo, ao se utilizar uma correlação entre complexidade e sistemas complexos, que seriam aqueles onde há a emergência de comportamentos complicados e imprevisíveis que não podem ser explicados como superposições da evolução das suas partes constituintes. Para compreender esses fenômenos se busca encontrar certos padrões de comportamento relacionados à frequência de algum tipo de evento e também uma certa tendência que esses sistemas teriam de derivar para estados críticos. Estudos foram feitos junto a populações de pacientes psiquiátricos para tentar estabelecer uma certa predição com relação ao comportamento humano, com base na maneira como esses pacientes se organizam em um pátio de um hospital psiquiátrico na busca de evidenciar certos padrões que pudessem ser analisados quantitativamente. Piqueira et al. (I999, 2007), assim como Ramos, Sassi e Piqueira (20I I), criticam estudos realizados neste campo baseados em conceitos determinísticos, não adaptados para explicar esses fenômenos complexos. Com relação aos resultados das suas pesquisas afirmam que apesar de terem obtido resultados interessantes, há grandes dificuldades para que seja feita uma previsão pois o comportamento das pessoas seria parte de um sistema mais amplo que inclui também questões relacionais. Haveria então, entre as suas características, uma relação entre o previsível e o imprevisível e a criticidade auto-organizada (SOC - Self Organized Critically) e que já haveria resultados mais robustos tratando de outros tipos de fenômeno, como os naturais.

Apesar de haver semelhanças entre as abordagens há uma diferença significativa. No caso da Teoria da Complexidade, a proposta seria o de entender os fenômenos sob um "olhar complexo", servindo para qualquer tipo de fenômeno, já a proposta desses autores estaria mais relacionada ao entendimento de 
sistemas considerados complexos. O foco não estaria portanto, em buscar uma tipologia para classificar os sistemas em mais ou menos complexos, mas sim uma maneira de encarar a realidade. Por outro lado, é importante salientar que esta tipologia pode ser útil no desenvolvimento de projetos de engenharia que não baseados em conceitos determinísticos.

Relacionar as propostas da ergonomia com os preceitos da Teoria da Complexidade não é muito comum em trabalhos e em discussões neste campo, o mesmo pode ser dito com relação às ciências da organização. Todavia algumas tentativas já foram feitas com esse propósito, como em Montedo; Sznelwar (2008); Dudziak; Sznelwar e Plonski (2005) e Borgatti (2007). Sem relacionar com a atividade de trabalho propriamente dita, Carayon (2006) discute a importância de se olhar de forma diferente os fenômenos tratados em ergonomia, incluindo a complexidade como um pressuposto para conceber a organização da produção e do trabalho. Trata-se de sistemas dinâmicos e que os resultados só serão satisfatórios se houver uma constante intervenção dos diferentes atores, isto é, a produção depende do trabalho vivo.

Este teoria que permite ligar conceitos e, sobretudo de colocar em relação dialógica, pontos de vista distintos, oriundos das disciplinas que compõem o espectro de conhecimentos necessários em ergonomia. Ressalte-se que trata-se de um posicionamento que visa entender a análise ergonômica do trabalho, que está voltada para a compreensão e transformação, em consonância com os preceitos de uma visão "complexa”. Isto reforça a importância de se tratar as situações de trabalho em sua singularidade, entendendo a emergência de diferentes fenômenos, em consonância com a dinâmica da produção que é sempre situada.

Apesar de já podermos encontrar nos trabalhos de Wisner uma abertura neste sentido, ele não propõe uma ruptura paradigmática com as ciências mais tradicionais, ainda permeadas por uma visão mecanicista. A sua preocupação em garantir uma certa cientificidade para a ergonomia lhe coloca numa postura mais cautelosa, todavia, em momento algum ele propõe uma simplificação da realidade, mesmo que ele oriente as suas propostas para alguns recortes do trabalho desenvolvido nas situações reais (WISNER, I972/I995d). Mas ao analisar mais em profundidade o que ele próprio propõe, seria necessário reconhecer que há um ponto de vista complexo, uma vez que para entender a realidade, há sempre uma busca em correlacionar os fenômenos existentes.

Reforçar a relação dialógica entre o entendimento relativo às diferentes variáveis que entram em jogo na constituição das atividades de trabalho e, em um momento posterior, as soluções construídas para resolver algum problema, permeadas de pragmatismo e, que, em princípio, seriam o fruto de decisões adotadas a partir de negociações entre os atores sociais em questão poderia ser uma das contribuições deste olhar. Por exemplo, como decidir os caminhos a serem 
adotados quando um sistema de produção está na beira da saturação, como pode ser o caso de uma central de atendimento a clientes ou um sistema de controle de tráfego aéreo? Quais serão os pontos de vista que entram nos processos de decisão? De que forma, as atividades de trabalho entram em questão para ajudar a construir decisões mais favoráveis que considerem tanto a disponibilidade de recursos, a confiabilidade dos sistemas e a saúde dos trabalhadores? Assim, as soluções dependerão de como se constrói uma discussão mais rica, colocando em cena, os diferentes pontos de vista, criando a possibilidade de se constituir uma relação dialógica, onde é possível explicitar os conflitos e, decidir quais soluções serão adotadas. Para tanto, a adoção de métodos que permitam analisar tanto qualitativamente como quantitativamente os fenômenos pode ser bastante útil.

A necessidade de adotar este tipo de ponto de vista fica também evidente no caso das medidas de proteção dos trabalhadores frente a algum risco. Ao propor a adoção de equipamentos de proteção individual como o caminho mais prevalente, as empresas desconsideram todo o restante com relação à atividade dos trabalhadores e, mesmo o seu conforto para trabalhar. Retornando ao que já foi dito anteriormente, sem entender o que se passa na realidade, qualquer solução pode estar fadada ao insucesso, ou ainda a criar um outro problema, como incômodos, uma falsa proteção ou ainda uma dificuldade para se obter informações pertinentes para o desenrolar das atividades.

Um outro conceito que distingue o ponto de vista complexo do que é preconizado pela Escola Clássica da Organização (Organização Científica do Trabalho - OCT, proposta por Taylor) está relacionado com a ordem e a desordem. A OCT é proposta com uma forte perspectiva de ordenamento dos sistemas de produção, indicando que haveria uma única solução ótima e que os procedimentos de referencia para as tarefas exigiriam que os trabalhadores os cumprissem à risca. Isto mostra que há coerência com relação à cientificidade adotada nesta abordagem, baseada em propostas simplificadoras da realidade e em pressupostos oriundos de uma visão positivista. No caso da Teoria da Complexidade, a proposta é justamente de olhar o mundo sob outra perspectiva. Neste caso não se trata da ordem em uma direta oposição a desordem, sendo que a primeira seria algo a ser estabelecido e mantido tal e qual. No olhar da complexidade a relação entre ordem e desordem seria dinâmica, algo sempre entremeado. Não haveria um processo único e determinado, quando pensamos nos sistemas vivos, como o é uma empresa, uma instituição. A desordem seria necessária para que outros níveis de ordenamento sejam possíveis; assim para evoluir, qualquer sistema precisa dela, ainda mais porque todos os sistemas seriam entrópicos e a energia não poderia simplesmente ser acumulada, de alguma maneira ela precisa ser direcionada, modulada para um determinado fim. Haveria uma constante 
relação entre o desordenamento e o ordenamento, um processo fundamental para que os sistemas não pereçam.

Ao pensar na própria vida do ser humano, mesmo se nos ativermos à fisiologia, há no corpo uma série de sistemas de auto-regulação que impedem que a tendência à desordem, torne impossível continuar vivendo. Todavia a cada novo momento, um outro patamar é atingido, um novo modo de funcionamento, dentro de certos limites, é adquirido.

A Teoria da Complexidade teria também a ver com as ideias relativas a uma visão mais sistêmica das organizações humanas. Ao propor o princípio hologramático, Morin afirma que há em todos os componentes de um sistema vivo, a essência do sistema como um todo, haveria algo que permite estabelecer conexões pois essas "partes do sistema" são compatíveis entre si. Ao interpretar esse conceito à luz da organização da produção, é possível entendermos que a coerência buscada está relacionado com certos preceitos que valem para ela em seu conjunto e que os modos de regulação tem a ver com o que há de comum entre os seus diferentes componentes. No caso da proposta da Análise Ergonômica do Trabalho, a busca de um entendimento mais geral sobre como se organiza uma empresa ou instituição e, de que forma isto se traduz no desenho das tarefas, permite não apenas compreender o que se passa naquela situação de trabalho, mas sobretudo o de trilhar caminhos de solução que procurem colocar em relação os diferentes pontos de vista que a compõem, numa tentativa de ampliar o espectro de soluções possíveis.

Ao situarmos a abordagem da ergonomia como uma ação que visa uma transformação, poderíamos entender que não se trata de uma proposta uma simplificação da realidade, mas com todas as dificuldades que isto pode acarretar, o de colocar em relevo a complexidade da situação de trabalho. Assim talvez se possa afirmar que a AET proporciona um olhar complexo sobre o trabalhar e isto possibilita a busca de diagnósticos mais ricos e a construção de soluções distantes daquelas que preconizam critérios únicos e otimizados visando um bom funcionamento, para as máquinas, para os sistemas e para o ser humano. Haveria sim, uma constante regulação feita por diferentes atores que agem.

Compreender o trabalho, baseados numa perspectiva desenvolvida pela AET, incluiria um diálogo com a Teoria da Complexidade, com base em certos conceitos, além do paradigma hologramático, já citado. A relação entre ordem e desordem, a recursividade, a auto-poiese, entre outros, podem ser úteis. Ao adotar este ponto de vista é possível evidenciar aquilo que não é visto, portanto não compreendido, a partir de um olhar desavisado, enriquecendo o conhecimento sobre aquilo que é feito, como no caso de agricultores que desenvolvem estratégias para conciliar o seu próprio trabalho com questões gerenciais em pequenas propriedades rurais (MONTEDO; SZNELWAR, 2008). Os autores mostram, 
que há um risco de que eles próprios incorporem um ponto de vista depreciativo sobre o seu trabalho, principalmente quando recebem instruções técnicas, sem que aqueles que prestam serviços de apoio considerem as diversas questões de produção e de trabalho que estão em jogo. $\mathrm{Na}$ realidade, constroem compromissos entre diferentes racionalidades que devem considerar para produzir, fato que mostra a riqueza do seu pensamento e dos seus conhecimentos, mesmo que não tenham consciência deste fato. Este tipo de abordagem nos permite também, saindo do paradigma positivista mais tradicional incluir também a perspectiva da incerteza, da instabilidade e a das inter-relações entre os mais diferentes subsistemas que compõem um determinado ambiente de produção.

Enfim, as organizações devem ser analisadas como sistemas vivos, onde apenas parte delas é composta por materiais, objetos, por coisas. As máquinas funcionam em consonância com um determinado programa. O seu funcionamento, por mais desenvolvido que seja, depende daquilo que lhe foi imputado e previsto por profissionais que conceberam o seu programa. Assim, contrariamente àquilo que é considerado como vivo, o funcionamento das máquinas não lhes permite criar, a desordem não pode ser admitida, mesmo que haja uma certa margem nos seus parâmetros de funcionamento, como no caso em que, no programa, estão previstas algumas variações. Em qualquer situação de trabalho, os trabalhadores terão (ou deveriam ter) como apoio objetos que, através do seu uso, possam atingir os seus objetivos. O que há de maquinal, mesmo que seja altamente sofisticado, depende, de alguma forma, do humano para que funcione.

Qualquer sistema de produção é constituído por uma parte significativa daquilo que é do mundo vivo, as pessoas! Isto vale tanto para o sujeito em si, como no que tange ao convívio com os seus colegas, com a hierarquia e com os clientes. Há que se considerar também as profissões, onde se trabalha com outros seres vivos não humanos, como no caso de animais e plantas. Aí também se constitui uma atividade significativamente diferente do trabalho industrial, pois não se trata de uma relação com objetos.

A questão da estratégia é uma das componentes importantes do trabalho vivo. Ela é parte inerente à vida, todos os organismos, de alguma maneira, desenvolvem algum tipo de astúcia para conseguir sobreviver e garantir a continuidade de sua espécie. Como aqui a questão está no trabalho, sob um ponto de vista exclusivamente voltado ao humano, o que está em jogo é a capacidade dos sujeitos em criarem soluções, em darem conta das dificuldades que encontram para produzir, ao buscarem compromissos entre as exigências das tarefas e as condições para desenvolver a sua atividade, da sua capacidade de aprender, enfim o de se enriquecer pessoalmente através das experiências compartilhadas com outros atores que trabalham. 
A visão aqui tratada se situa em oposição à existência de sistemas homemmáquina, uma vez haveria então o risco de colocar num mesmo patamar aquilo que é vivo e aquilo que é inanimado na produção. São universos incomensuráveis, não se pode imaginar que um ser humano possa ser comparado com um recurso, com uma coisa. Reificar os sujeitos é um erro, sempre traz consequências nefastas tanto no que tange a saúde dos trabalhadores, como no que diz respeito ao desperdício de recursos materiais. Os únicos integrantes de um sistema de produção que podem ser desenvolvidos são os trabalhadores (HUBAULT, 20I Ia), os humanos. Todos os outros recursos são utilizados, são consumidos podendo, em certos casos até serem reciclados.

A ergonomia ao se posicionar em um horizonte transformador, assume um papel para impulsionar novas soluções técnicas e organizacionais. Aquilo que não está adequado às características humanas pode ser transformado. Ao menos para algumas empresas, instituições ou mesmo em setores da economia, isto se tornou um forte impulsionador para a gênese de inovações.

A evolução da sociedade traz cada vez mais desafios para que os sistemas de produção sejam melhorados. Um dos desafios fundamentais está relacionado com o envelhecimento das populações, hoje graças ao conhecimento existente em diferentes campos, o ser humano vive mais, uma quantidade maior de pessoas consegue atingir idades mais avançadas. Há uma tendência para que seja necessário que as pessoas trabalhem por mais tempo, permanecendo ativas em idades que antes estariam aposentadas, ou até, já teriam falecido. A este fenômeno se adiciona uma postura de incluir no mundo da produção, pessoas que tenham necessidades especiais e que antes viviam na dependência do Estado, da benevolência dos outros ou do resultado de trabalhos informais com pouca repercussão nas empresas e nas instituições. Assim, a frase de Wisner, “a qual trabalhador o trabalho deve se adaptado" está mais do que em voga, uma vez que, nos preceitos da ergonomia houve sempre uma busca de permitir que este seja desenvolvido por uma quantidade cada vez mais ampla de pessoas, cobrindo um amplo espectro se considerarmos uma distribuição normal das características das pessoas.

O que então é proposto pela ergonomia se situa numa inversão radical com relação aos conceitos mais prevalentes nas indústrias no século XX. Assim, é possível considerar que um projeto seria mal concebido se o trabalhador tiver que se adaptar a máquinas projetadas a partir de uma lógica funcionalista, onde o que prevalece é uma perspectiva de enquadrar as pessoas para que funcionem de modo adequado ao operarem as máquinas. A referência a um trabalhador médio, bem treinado, atuando em uma situação estável, mantendo um desempenho constante não seria mais adequada, aliás como nunca, de fato, o foi. Os desafios para projetar e gerenciar os sistemas de produção, considerando o que propõe a ergonomia exigem inovação e isto não é utópico, tendo em vista as 
contribuições que houve ao se incorporar uma visão mais ampla sobre o ser humano no mundo da produção, os resultados tanto para a saúde como para os da produção são significativos, assim como para o desenvolvimento da sociedade (WISNER, I97I/I995).

A amplitude de uma AET e, consequentemente a das soluções que podem ser construídas, em muito evolui nas últimas décadas. No início da ergonomia moderna, se pensou quase que exclusivamente em reduzir o conceito de situação de trabalho, ao posto de trabalho, guardando uma forte correlação, mesmo que em posição crítica, com o taylorismo clássico. Uma AET sempre teve este potencial de permitir uma visão de conjunto coerente, todavia de modo pragmático, muitas vezes, as questões tratadas seriam as mais visíveis e palpáveis. Assim, através das soluções propostas, ficaria mais claro que os aportes da ergonomia são desejáveis, todavia não se perderia uma visão de conjunto, evitando que uma melhoria trouxesse outras dificuldades e riscos para os trabalhadores. Este momento da história da ergonomia, situado sobretudo na década de I960, já passou, hoje a possibilidade de participar no debate e na construção das transformações que incluam questões mais amplas, como por exemplo, as ligadas ao projeto da organização do trabalho é mais frequente e faz parte de diferentes demandas das empresas e das instituições.

Construir uma coerência entre os diferentes aspectos da produção, respeitando o princípio que, ao se constituir como sistema, haja uma consonância entre os seus diferentes componentes é um desafio, ainda mais quando está em pauta a questão do trabalho e do protagonismo. Está em jogo portanto, uma redução do risco de haver, numa mesma empresa ou instituição, contradições significativas entre, por exemplo, aquilo que se preconiza e se afixa em público, incluindo a imagem veiculada sobre a empresa e a realidade da produção. Isto vale não apenas para aquela organização em si, mas para a própria rede de produção, incluindo outros atores que a compõem.

Esta preocupação, de certa forma, já estava presente no pensamento de Wisner na década de I960, quando ele se mostrava cauteloso no que diz respeito à magnitude dos resultados de uma proposta de melhoria centrada no posto de trabalho e respeitando, por exemplo, aspectos fisiológicos do trabalho, exclusivamente. Não necessariamente isto resultaria em melhores condições para o trabalhador, pois, ao se propor alguma solução, como a adoção de pausas para reduzir a quantidade de repetições de determinados gestos, pode-se, por outro lado, aumentar as cadências e piorar a situação para quem está produzindo. Wisner (I966), neste momento, dá uma prova de humildade, pois ao evocar os limites dos conhecimentos existentes à época e, mesmo a pouca abrangência de uma ação ergonômica restrita a apenas alguns aspectos do trabalho, afirma que haveria muito a evoluir, considerando-se inclusive outros pontos de vista. 
Apesar da crítica de se basear apenas em conhecimentos oriundos da fisiologia, isto não invalida a sua importância, uma vez que se trata de uma referência importante para projetos (WISNER, I973 / I995). Mesmo sendo uma visão reduzida, inclusive porque a maioria dos estudos provém de situações experimentais, portanto controladas e bastante distintas do mundo do trabalho, esses conhecimentos são úteis. Aliás esta é a perspectiva adotada tradicionalmente pela abordagem Human Factors que, apesar de desconsiderar a atividade real, preconiza que os projetos das tarefas considerem o conhecimento já existente sobre o ser humano, principalmente em relação aspectos fisiológicos e cognitivos.

Todavia, tratar esses parâmetros como algo a ser seguido sem considerar a atividade de trabalho pode ser um problema, uma vez que, ao adotarem como base algumas regras a serem seguidas, há o risco de não se tratar da conjunção de aspectos que compõem a atividade, como, por exemplo, o contato com diferentes agentes agressivos, ou ainda a interferência de agentes ambientais com as possibilidades de aquisição da informação, entre outros.

Para a ergonomia, seria importante se adotar uma tensão, uma relação triádica entre os conhecimentos oriundos de experimentos, aqueles oriundos das situações de referência e a realidade que está sendo considerada. O próprio resultado das análises em situações reais de trabalho é útil tanto para questionar o que já existe no âmbito da ergonomia como no das ciências com as quais dialoga, pois pode impulsionar novas pesquisas, e mesmo novas experimentações, para que se encontre alguns parâmetros mais adequados.

Há perguntas que, provavelmente não terão uma resposta bem elaborada ou que seja única. Assim, ao adotar qualquer solução em uma situação de produção é importante que se utilize da prudência, até porque, deve se considerar sempre a diversidade dos seres humanos e as mudanças que ocorrem ao longo da vida, mudanças que se inscrevem no corpo e na psique.

Este tipo de ponto vista é bastante próximo daquele que Wisner defendia desde o início da década de I970 (WISNER, I973/I975c). Para ele já era evidente que o trabalho não poderia ser concebido a partir de uma visão restritiva das capacidades humanas, como o que fora proposto pela Escola Clássica de Organização e que o trabalho deveria ser adaptado para o maior número de pessoas e não ser um critério de exclusão social. O trabalho deveria ser adaptado à população real e não ser baseado em conhecimentos oriundos do laboratório, onde no mais das vezes, a população estudada se restringia a jovens estudantes e jovens a serviço das forças armadas. $\mathrm{O}$ autor apresenta resultados de vários estudos, em laboratório e em situação de trabalho que mostram como indicadores fisiológicos, em especial ligados ao desempenho e à atenção podem ser úteis para avaliar o trabalho pois seria possível evidenciar que mudanças nas 
variáveis fisiológicas ocorrem antes das mudanças no desempenho. Reafirma que apesar de haver interesse nesse tipo de abordagem, há limites, pois não é possível reduzir a complexidade do trabalho a variáveis fisiológicas.

Aqui se delineou uma questão fundamental em ergonomia e na relação com as ciências da organização, uma vez que, o modelo proposto por Taylor e seus seguidores, apesar de trazer benefícios para o desenvolvimento da indústria, teria muitas consequências em termos sociais e para o trabalho em si, uma vez que, os pontos de vista defendidos e aplicados de modo bastante disseminado na indústria e, mais recentemente em serviços trariam no seu bojo uma ideia de redução da realidade, fragmentação dos processos de produção, de simplificação que, afetariam diretamente as possibilidades de aprendizagem, de ascensão nas carreiras profissionais, na saúde. Certos paradigmas, como o de que seria possível tudo prever e que haveria uma solução ótima para os problemas da produção, não seriam verdadeiros, tendo em vista que quaisquer modelos da realidade, apesar de poderem ser úteis, jamais a ela correspondem.

Esta tensão entre o que propõe a ergonomia da atividade e as ciências da organização traz para o debate questões fundamentais para uma visão mais abrangente do trabalho humano. A população é extremamente diversificada, a diferença é a regra e não a exceção, as pessoas envelhecem, têm sexos diferentes, escolaridade diferente, tem capacidades físicas diferentes, cada um adoece à sua maneira e os desejos são muito diversos também.

A humanidade não se encaixa no mundo restrito e pré-definido da produção industrial clássica, assim a adaptação do trabalho ao ser humano é um grande desafio pois inverte a questão, induzindo ao enriquecimento dos modelos e, de um modo mais radical, de substituição dos paradigmas científicos que os norteiam. Esses desafios não se colocam apenas para as ciências da organização, o mesmo ocorre com a própria ergonomia que, para se desenvolver, precisa dialogar com outras áreas do conhecimento, como a antropologia, a sociologia, a psicodinâmica do trabalho.

O diálogo se coloca de modo significativo em relação às ciências que compõem o espectro da arte da engenharia. Em artigo do início da década de I970, Wisner, reforça a importância do debate com outras disciplinas ao afirmar que para o ergonomista é importante entender as estruturas, técnicas, econômicas e sociais onde está situada a sua ação, assim não haveria uma ergonomia situada fora do contexto da produção. Tanto as possibilidades de entendimento, de transformação e as restrições com as quais o ergonomista terá que dialogar são sempre contextualizadas, dependem das relações sociais de produção, do desenvolvimento técnico e das condições econômicas (WISNER, I972/I995d).

A influência da antropologia fica evidente uma vez que se trata de compreender não apenas a atividade humana, mas a produção em uma determinada 
organização, situadas no tempo e no espaço (WISNER, I99I). Isto reforça a perspectiva que não se faz ergonomia sem que haja uma profunda discussão, uma ampla cooperação com outras áreas do conhecimento.

O papel do ergonomista não seria o de um especialista que conhece o trabalho e que, portanto o de alguém que deveria construir um diagnóstico e as soluções isoladamente; é em relação com outros atores sociais, detentores de outras perspectivas que se torna possível fazer avançar as situações de trabalho. Isto também vale para o próprio conhecimento na área, construído na relação com outros campos da ciência. 


\subsubsection{Sobre a abordagem na ergonomia da atividade}

Conforme já dito anteriormente, a Análise Ergonômica do Trabalho (AET) que teria como finalidade principal a de desvelar aquilo que é pouco ou nada conhecido no trabalho, isto é, a atividade humana para produzir algo ou algum serviço tem, na realidade, outros objetivos. Esta afirmação tem a ver com aquilo que já foi dito por vários autores (WISNER, I972, I99I, I995)(GUÉRIN et al., 200I). Estes objetivos seriam principalmente ligados à constituição de um processo nas empresas onde, ao se desvelar a atividade, estar-se-ia também construindo um processo social no qual diferentes atores teriam um papel fundamental, enfim, seriam também protagonistas de uma ação visando a compreensão e a transformação. De algum modo, estaria em jogo a própria organização da empresa, uma vez que ao buscar um entendimento mais amplo sobre o trabalho e ao procurar colocar em evidência, diferentes pontos de vista, uma AET tem, no seu âmago uma perspectiva de permitir que haja espaço para que as pessoas possam falar sobre o seu trabalho e sobre o trabalho dos outros, seja em termos mais próximos da sua atividade propriamente dita, ou sobre as tarefas que, em parte podem ser de sua responsabilidade. Enfim, diferentes atores, estariam, ao menos em princípio, envolvidos neste processo e, tanto o diagnóstico, como as soluções a serem construídas, seriam de melhor qualidade a depender da qualidade do envolvimento deles.

Uma AET poderia ser considerada como uma mudança nos processos organizacionais tradicionais. Trata-se de um posicionamento político, pois considera os pontos de vista de diferentes atores, possibilitando uma visão mais democrática do que seria a produção e o trabalho. Isto não significa que assim o seja em todas as circunstâncias e nem que o sucesso esteja garantido. Como todos processos sociais, há que se considerar o controverso, as disputas, os jogos de poder e, também as possibilidades de transformação, ditadas pela visão estratégica dos responsáveis pela direção das organizações.

Dentre os desafios para atingir os objetivos que serão definidos em cada situação, há a questão de como, os diferentes argumentos serviriam para que os processos de decisão sejam melhor embasados. Todo processo de decisão é baseado na incerteza, mesmo que haja evidências significativas sobre aquilo que se quer demonstrar, o próprio fato de ter que decidir, significa que há alternativas possíveis e que também não há garantias com relação aos resultados. Assim, tratar com bastante cuidado os problemas e dar evidência às diferentes perspectivas não é simplesmente colocar na mesa de discussões os indicadores que seriam os mais tradicionais, utilizados para avaliar a produção.

No que diz respeito à ergonomia, há muitos fenômenos que não tem indicadores para tal. Um deles seria a própria atividade. Como medir algo que pouco 
se conhece e sobretudo, como medir algo que é íntimo à pessoa. Trata-se, por exemplo, dos processos cognitivos. Não é possível ter quaisquer evidências de como as pessoas tratam as informações a partir de indicadores mensuráveis, quando muito se tem acesso a parte deste processo, através da fala, do testemunho dos trabalhadores. Assim, o que temos acesso sobre a cognição é a sua expressão, o resultado, jamais os processos em si. No caso dos indicadores fisiológicos, apesar de já existir uma gama de fenômenos mensuráveis, eles sempre são parciais e, no mais das vezes indicam os resultados de algum processo e não o processo em si. Por exemplo, ao analisar um eletroencefalograma, podemos fazer uma relação entre o fisiológico e o os processos mentais, mas não temos acesso ao pensamento, apenas a uma certa expressão de uma determinada atividade, isto é, temos conseguimos evidenciar fenômenos elétricos que se passam no cérebro e que servem para indicar algo sobre o funcionamento cerebral. Quando se trata do conteúdo simbólico de um pensamento ou de um sonho, quando muito conseguimos aceder a algo através da fala, algo sobre, mas não ao fenômeno em si.

Essa discussão evidencia que os métodos são uma expressão de escolhas epistemológicas e que, sob nenhuma circunstancia poderíamos considerar que haja algum que dê conta de tudo, aliás o conceito de totalidade é falso pois não se sabe os limites de um determinado fenômeno, ainda mais quando se trata de sistemas sociais como os de trabalho. A AET se fundamenta numa crítica aos métodos experimentais e, desde a década de I950, esta abordagem começa a se distanciar dos métodos experimentais, dominantes no início da ergonomia moderna, em acordo com o que propunham Faverge, Ombredame e Pacaud, pioneiros neste campo. Desde o início, a AET, ao tratar como fundamental a ação dos trabalhadores para dar conta da discrepância entre o prescrito e o real, permite que se considere os dois protagonismos propostos neste texto, principalmente o fato que sem um trabalho para ajustar ao real os procedimentos previstos nas tarefas, não há produção que saia a contento. Ao se basear na realidade e, sobretudo na ação dos sujeitos, a AET permitiu muitos avanços, uma vez que resultados significativos foram obtidos ao longo do tempo, tanto no que diz respeito ao conhecimento sobre o trabalho como com relação à qualidade das soluções construídas.

Outro ponto que também merece destaque é que AET é conduzida duplamente, pela realidade do trabalho e pelas condições sociais nas quais se constitui a abordagem em cada situação. Assim, é a singularidade que, em primeira instância, define o que se encontrará como resultados dos estudos. As hipóteses se constituem ao longo do processo, não podendo portanto, ter uma definição anterior, mesmo que os ergonomistas tenham conhecimento sobre alguma situação semelhante. Trata-se, sobretudo de uma abordagem indutiva. 
Há que ressaltar também um outro componente fundamental de uma ação em ergonomia que é a sua profunda relação com as demandas sociais, acompanhando a evolução da sociedade nos seus aspectos técnicos, sociais, nas relações de trabalho e, no caso de produtos, das questões ligadas ao consumo. Essa demandas modulam as ações, uma vez que podem partir de questões e de atores sociais diferentes. Todavia, cabe aos profissionais que trabalham com este tipo de abordagem, cuidarem para que diferentes pontos de vista ajudem a enriquecer os processos de análise para evitar que haja um ponto de vista único ou preponderante. Aqui reside um dos aspectos que revelam a dificuldade de se instituir um processo de ação que guarde esta perspectiva, uma vez que é necessário que diferentes atores participem, ou melhor, se envolvam para que melhores resultados sejam obtidos. Quão distantes estamos dos métodos experimentais, mesmo que estes guardem um certo interesse para compreender alguns aspectos dos fenômenos do trabalho e das atividades humanas!

Isto reforça a profunda relação da ergonomia com outras disciplinas, tanto na sua dependência com relação a elas, como na sua contribuição para o desenvolvimento delas. A forte inspiração na antropologia se dá pelo fato de situar a sua ação em um determinado cenário onde os seres humanos vivem. Ainda, há situações em que pode ser considerada um análise baseada na observação participante. Todavia, a proposta da ergonomia não é o de descrever, entender e interpretar o trabalho unicamente; a sua proposta é de transformar o trabalho, transformar aquela realidade de produção. Já no caso da antropologia, ao respeitar as diferentes culturas e sociedades humanas, não teria como objetivo de transformá-las.

A ergonomia da atividade não partiu de uma certa teoria para se desenvolver em seguida, o ponto de partida foi muito mais uma constatação empírica ligada à discrepância do real com o prescrito. Não se constata que, ao seus primórdios havia uma preocupação mais direcionada com uma teorização tanto do método como o de que seria a atividade humana de trabalho. Isto reforça a ideia de que a ergonomia seria uma arte e que necessitaria do aporte de outras áreas do conhecimento para se desenvolver, guardando uma relação dialética entre a importância do campo e uma crescente reflexão sobre a ação situada (WISNER, I99I). Ao considerar a ergonomia, nesta perspectiva, abre-se campo para reflexão tanto para a questão da atividade dos trabalhadores nas situações de trabalho, como também para uma reflexão sobre a própria prática da ergonomia e os seus caminhos ao longo de sua história. (DANIELLOU 2004) (HUBAULT, 2004)

Esta abordagem não se posiciona na definição daquilo que seria certo ou errado, baseada em parâmetros anteriormente determinados, mas sim, para melhorar as situações de trabalho pois, ao haver alguma demanda, já haveria 
algum problema a ser melhor conhecido e alguma solução a ser construída. Em respeito aos diferentes atores sociais e à realidade encontrada, fica evidente que, toda situação é singular e que as propostas de uma AET não são a de universalizar esses conhecimentos, como se fossem adaptados a qualquer situação. Por outro lado, quaisquer resultados de AETs podem ser úteis para outras situações, servindo como referência também para projetos de novas situações de produção e de trabalho (DANIELLOU, 2006).

A dinâmica social que se constitui em um processo de análise e transformação requer que se construam compromissos, frutos de processos de discussão, de conflito, de negociação e de decisão. Assim, em princípio, uma ação ergonômica, que resulta da ação de diferentes atores agindo nas organizações, reflete diferentes tipos de protagonismo, tanto dos ergonomistas, como de todos que participam, cada um exercendo papéis distintos e que, podem ser mutuamente enriquecedores, no que diz respeito tanto ao conhecimento do que vive o outro numa situação de trabalho, como os de seus pontos de vista.

A defesa do protagonismo poderia ser também um resultado de uma postura defendida pela ergonomia da atividade, isto é, a do reconhecimento da inteligência daqueles que trabalham, não importando a qual tarefa a pessoa esteja alocada. A inteligência, tema importante da psicologia cognitiva, é tratada também pela psicodinâmica do trabalho, entre outras áreas do conhecimento, principalmente quando são colocadas em evidência a astúcia (DEJOURS, 20 I Ib) e a incorporação da experiência (MATURANA e VARELA, I994).

Fica claro então, que certos conceitos utilizados largamente na indústria, em especial quando se trata de questões ligadas ao estudo de acidentes são, senão falsos, incompletos e pouco operacionais para induzir melhorias. Dentre eles a noção de erro humano é um expoente, uma vez que, ao buscar culpabilizar o sujeito por algum evento não desejado, despeja-se naquele indivíduo a responsabilidade por toda uma série de inadequações que tem origem no projeto dos equipamentos, na organização do trabalho, na gestão e também na sua própria ação, como se houvesse uma questão unicausal a ser desvendada. Além da injustiça deste tipo de colocação, ela não induz melhorias; os estudos em ergonomia mostraram que as pessoas fazem muitas coisas para evitar os acidentes e, quando adotam condutas mais arriscadas, o fazem por exigências de produção e pelo zelo que teriam para que esta saia a contento.

A inadequação deste tipo de conceito, o de imputar ao erro dos trabalhadores que estão na operação propriamente dita, a causa dos acidentes considerados como de menor monta, quando alguém se lesiona em alguma atividade, é também totalmente inadequado quando se trata de acidentes considerados como de grande monta (maiores ou catastróficos). Neste caso, há muita discussão proposta por diferentes autores que evidenciam a questão do acoplamento 
de variáveis que conduzem a um acidente e que não poderiam ser imputadas à ação ou a um comportamento inadequado de um trabalhador na operação exclusivamente. Este conceito de ato inseguro já está e, acredito eu, sempre esteve, ultrapassado. Trata-se de uma questão ligada à conjugação de fenômenos e que tem a implicação de diferentes atores sociais. Quando Perrow (I984) trata da questão usando a denominação de "acidentes normais", fica em evidência a questão da relação entre as variáveis, isto aproxima dos pontos de vista defendidos na Teoria da Complexidade (Morin, I990). Assim poderíamos tratar da questão buscando relacionar as variáveis para melhor compreender a emergência de fenômenos indesejáveis como os incidentes e acidentes.

Esta discussão, relativa à inteligência e ao erro humano está em evidência nas demandas que emanam das organizações para a ergonomia sobretudo com o advento da automação e da informatização dos sistemas. Desde no uso de um computador pessoal, até na condução de sistemas de produção contínua como os de uma refinaria de petróleo há uma questão fundamental. Será que a sua concepção, projeto e gestão das operações é feito considerando-se as capacidades e limites da cognição humana? A questão se coloca frontalmente para a ergonomia, uma vez que não está em causa um conhecimento oriundo de estudos experimentais, mas do confronto cotidiano com sistemas que são de difícil entendimento, que tem problemas de lógica, de congruência, de dificuldade de distinção ligada à apresentação das informações, e às possibilidades de navegação em um determinado programa para que os objetivos da ação sejam atingidos de modo o mais fácil possível. Questões do uso e da usabilidade dos programas informatizados que, também estão na base dos automatismos na produção, se tornaram centrais em ergonomia, uma vez que não se tratava de uma questão unicamente de saúde ou de segurança, mas porque o seu funcionamento era inadequado. Aliás, desde os primórdios da ergonomia moderna, esta questão está colocada. O domínio do trabalhador sobre a máquina ou a dominação desta sobre o trabalhador é uma questão em aberto. Sistemas fechados que impedem uma conduta mais livre da pessoa podem ser tanto mais seguros como muito mais perigosos quando se trata da gênese de acidentes.

O foco na ergonomia não está no erro em si mas na origem de ações mal sucedidas. A questão da contribuição do trabalhador com o seu conhecimento para que os sistemas de produção funcionem também já é um fato praticamente incontestável, desbancando um dos conceitos fundadores do taylorismo baseado na ideia da mera execução. O conhecimento adquirido nos estudos sobre a atividade humana no trabalho mostram que face ao real, onde qualquer trabalhador precisa tratar de diferentes tipos de informação que ele adquire através de toda uma estratégia para conseguir captar aquilo que é relevante nos leva a considerar que, em qualquer situação, o que se busca é entender quais são os 
problemas, constituí-los, para então, buscar soluções, através de algum tipo de ação. A importância da informação fica ainda mais evidente quando, em algumas situações, os trabalhadores se veem sobrecarregados e não conseguem dar o devido tratamento para agir, inclui-se também as situações onde é necessário tratar de informações conflitantes, quando não contraditórias. Esses casos, muitas vezes extremos, podem ser ilustrados pelos relatos e por dados obtidos quando do acontecimento de acidentes maiores, como os da Usina Nuclear de Tchernobyl, da planta da Union Carbide em Bhopal, do acidente no voo AF 452, entre outros.

Note-se que o conhecimento obtido a partir desses eventos que ocorreram, muitas vezes, em situações muito degradadas reforçam a ideia que medir a "carga de trabalho", ainda mais quando nos referimos a questões cognitivas não resulta em algo concreto. Medir e, consequentemente se propor indicadores, fato típico de uma visão positiva da ciência, é como se posicionam aqueles que buscam reduzir a realidade aos parâmetros de gestão. Note-se que há uma diferença fundamental entre analisar uma situação considerada degradada, que levou a um patamar crítico, altamente entrópico e que, muitas vezes, terminou em um incidente ou acidente, e uma situação considerada como corriqueira. No primeiro caso trata-se de uma tentativa, através dos mais variados tipos de registro, de recuperar dados que possam nos aproximar dos fatos que ocorreram, isto é uma análise a posteriori. Muito se obtém do conhecimento a respeito, sobretudo quando a informação está inscrita, registrada em algum meio. Os dados obtidos em uma situação considerada como corriqueira, ou ao menos provável, busca-se analisar ao nos basearmos numa AET, como as pessoas agem naquela realidade. Esta análise situada permite a obtenção de conhecimentos que nos trazem à luz informações importantes, como as estratégias desenvolvidas pelos trabalhadores, para tratar a informação e para o desenvolvimento de um conhecimento distribuído que permita uma ação em equipe. Em ambos os casos, obtém-se resultados fundamentais para a melhoria dos processos de produção mas não se pode obter resultados que nos permitam medir efetivamente a carga mental de trabalho, quando muito, como já dito anteriormente podemos ter evidências de sobrecarga. No caso das situações degradadas, isto fica, muito evidente pois a qualidade das trocas entre os trabalhadores e a quantidade de informações que chegam em tempo real para que eles busquem trata-las é crescente, confusa, caótica, fatos típicos de um processo altamente entrópico.

Dentre as contribuições da ergonomia para o desenvolvimento dos sistemas de produção e para o próprio protagonista, ressalta-se também a questão da aprendizagem. Há muito se sabe, fato típico da produção dita artesanal e, também dos sistemas de aprendizagem profissional que, apesar da sua importância, os treinamentos, principalmente baseados na teoria, tem limitações para que, de 
fato, se aprenda a trabalhar. Para todas as profissões, o fato de haver aprendizes reforça a necessidade de se aprender também na prática, corroborando a importância deste tipo de conhecimento e postura tradicionais. Apesar disso, pouco se explicita e, como consequência, pouco se formaliza com relação aos fatos que ocorrem ao curso da atividade de trabalho. Isto é tão notório que, muito daquilo que fazem as pessoas não tem uma denominação, não há palavras para designá-lo. Ao fazer uma AET, uma parte deste saber - fazer emerge e pode se tornar explícito e isto é útil para aprimorar as trocas entre os trabalhadores que desenvolvem as mesmas atividades e, também para o aprimoramento dos sistemas de aprendizagem nas organizações. Evidentemente que este conhecimento não serve apenas para constatar uma situação e melhorar as formas de aprendizagem, ele é fundamental, como já afirmado anteriormente para embasar as mudanças que são necessárias e que facilitam, através da sua incorporação nos projetos, o trabalho em si. Assim também é fundamental que este tipo de conhecimento ajude a balizar e construir as soluções de melhoria, com um envolvimento efetivo dos atores, dos protagonistas.

Wisner (1982/I995a), propunha uma visão construtivista do conhecimento, para ele, no mundo real não haveria um problema dado, como existe nos enunciados utilizados para os processos de aprendizagem na escola tradicional. Neste caso, é no próprio enunciado que estão implícitas as bases para se encontrar a solução que, em geral, é única. Para tanto basta entender o que está sendo proposto, descobrir que tipo de problema é, encontrar os algoritmos condizentes e desenvolver o caminho de solução através dos cálculos e do sequenciamento dos algoritmos considerados como pertinentes. Na vida real não há problema dado, há várias soluções possíveis, mesmo a construção do problema pode ser mais ou menos enriquecida com a incorporação de novos aspectos e novos pontos de vista. Compete aos sujeitos, ao desenvolver suas ações, construir os problemas e desenvolver as soluções. Na realidade, um problema jamais está pronto, produzir significa dar conta de questões que inexoravelmente emergem e que tem uma dinâmica a ser considerada, as questões não tem começo meio e fim, a narrativa da vida no trabalho está em constante renovação, em constante retroalimentação. Devido a esses fatos, é importante reforçar a perspectiva iterativa de uma AET, uma postura fundamental enquanto abordagem para compreender como as pessoas constituem os problemas no seu trabalho, o que ajudaria a potencializar as trocas entre os atores sociais na produção. Isto porque uma AET não se baseia exclusivamente na observação de comportamentos, mas no entendimento comum e compartilhado, na significação ou ressignificação das ações, através de diferentes técnicas de auto-confrontação e de validação.

O reconhecimento da inteligência do trabalho humano reforça a necessidade do diálogo com outras disciplinas, por exemplo, com a antropologia cognitiva, a 
psicolinguística e a sociolinguística. Wisner, ao propor uma maior amplitude da ergonomia para tratar questões ligadas a outros países que não a França, considera em seu escopo de análise e ação, questões ligadas às diferentes culturas onde as empresas multinacionais se implantam, integrando questões históricas e geográficas, funda o campo da antropotecnologia, como uma ergonomia relacionada a questões da transferência de tecnologia. Nas suas preocupações, fica evidente que ele busca afirmar e disseminar a ideia que não haveria sociedades mais ou menos inteligentes e que a repartição da inteligência na humanidade não responde a critérios que, por muitos anos, embasaram conceitos colonialistas e racistas. Além da inteligência do trabalhador, ao afirmar e ao orientar muitos trabalhos em outros países e, mesmo em diferentes regiões da França, Wisner pode defender a ideia que a inteligência é amplamente disseminada entre os povos, afirmando inclusive que a própria disseminação das empresas multinacionais ao longo do mundo é uma prova significativa deste fato, até porque em outros países e regiões que não aqueles de onde as empresas se originam, as condições para a produção, podem ser consideradas como degradadas em relação às originais. Assim, além da inteligência dos trabalhadores, de um modo geral, fica reafirmada a inteligência dos diferentes povos (WISNER, I994).

Este autor jamais aceitou o conceito de que haveria países desenvolvidos e países subdesenvolvidos, para ele haveria países desenvolvidos industrialmente e países em processo de desenvolvimento industrial. Nesta perspectiva a riqueza cultural não pode ser entendida a partir de um ponto de vista único e a-histórico, isto é, aquele que considera como desenvolvidos os povos que tiveram sucesso no mundo mercantilista e capitalista, mais concentrado nos países do hemisfério norte. Isto fica ainda mais evidente quando reconhece que o aporte de outras culturas, ao longo da história, foi fundamental para o desenvolvimento industrial e para a construção da cultura francesa e europeia. A antropotecnolgia se funda então em uma proposta que, pragmaticamente como a ergonomia, está voltada para melhorias em aspectos operacionais, nos interesses comerciais e no retorno dos investimentos, assim como melhoria da saúde das populações e das economias locais, através de um enriquecimento das trocas entre diferentes países e culturas. A noção de tecido social e industrial são pilares importantes para a compreensão das diferenças entre países e regiões, reforçando as relações com disciplinas próximas como a sociologia e a antropologia.

No caso específico da contribuição de Wisner com o desenvolvimento da ergonomia no Brasil, além de suas visitas e participação em muito eventos fundamentais para tal, ele orientou vários trabalhos de doutorado que ajudaram a constituir tanto a ergonomia da atividade como a própria antropotecnologia, através de comparações entre regiões distintas do Brasil e da comparação entre situações de trabalho no Brasil e na França (SZNELWAR, 2006). 


\subsubsection{A ergonomia e a questão psíquica}

A questão do psiquismo para a ergonomia nunca foi central para o seu desenvolvimento. Todavia problemas ligados à saúde mental no trabalho emergiram de modo contundente nos últimos anos, principalmente pela alta incidência de distúrbios depressivos e, em casos mais graves de suicídios relacionados ao trabalho. Mesmo que não houvesse uma preocupação da ergonomia com esses aspectos do ser humano, se considerarmos o próprio desenvolvimento da psicodinâmica do trabalho, já havia uma forte interlocução entre Alain Wisner e Christophe Dejours que, também fez uma formação em ergonomia, na década de I980. Ao trazer para o debate com relação à saúde no trabalho, aspectos que não haviam sido tratados diretamente pela ergonomia, criou-se a possibilidade de desenvolvimento diferenciado com relação a essas questões. Um dos marcos dessa interlocução foi a organização conjunta do primeiro Colóquio Internacional de Psicopatologia do Trabalho, em r984, em Paris (DEJOURS, VEIL, WISNER, I985).

A inclusão das questões psíquicas do trabalho nas preocupações da ergonomia pode ser encarada como um processo bastante complicado e pouco definido. Apesar de não haver uma proposta de dissociação dos seres humanos em partes e pedaços quando se discute a questão do trabalhar, uma vez que a atividade de trabalho resulta de um engajamento do sujeito que inclui aspectos fisiológicos, cognitivos, psíquicos, sociais e antropológicos, a inclusão de conceitos que possam dar conta de questões outras que as tradicionais em ergonomia, se faz a partir do posicionamento de ergonomistas e de outros profissionais e pesquisadores que se confrontam com esses problemas.

Além disso, esses problemas podem ser tratados a partir de diferentes abordagens oriundas de teorias muito distintas. Ao utilizar o termo psiquismo para tratar das questões "afetivas" do trabalho já é um posicionamento, pois este termo está muito mais próximo da antropologia psicanalítica do que outras abordagens da saúde mental, como a do estresse, ou ainda da dos chamados riscos psicossociais. O debate entre a ergonomia e a psicopatologia do trabalho que havia sido iniciado nos anos de 1980 e, depois com psicodinâmica do trabalho, vai se constituindo. Wisner, já afirmava que essas questões eram importantes principalmente ao dar ênfase às relações da cognição com o corpo e das expressões psicopatológicas de uma sobrecarga cognitiva (WISNER, I993a). Isto não faz com que ele tenha adotado aos conceitos da psicanálise, mas mostra que havia uma abertura e uma disposição para o debate, deixando claro que havia limites nas abordagens baseadas estritamente no cognitivismo, principalmente se houvesse uma desconsideração com o corpo. Outras questões psíquicas foram levantadas por esse autor, principalmente quando ele discute a questão da 
ansiedade dos trabalhadores oriunda das incertezas, dos problemas, da degradação das instalações, da impossibilidade de desenvolver um trabalho bem feito, de relações de trabalho deterioradas encontradas nas mais diversas situações de trabalho (WISNER i993b).

Wisner se mostrou favorável à evolução da psicopatologia para a psicodinâmica do trabalho, quando a questão da possibilidade de haver uma transformação do sofrimento em prazer começa a se delinear (WISNER, I993d), quando este campo do conhecimento se enriquece, deixando de focar quase que exclusivamente nas defesas psíquicas. A distinção entre esses dois campos é evidente, mas já para este autor fica em cena a possibilidade de um diálogo e, inclusive de uma certa complementaridade, são questões que a ergonomia não trata diretamente ainda porque esta não tem uma teoria do sujeito. Essa discussão é desenvolvida em outros trabalhos, como em Dessors e Laville (2009) onde os autores discorrem sobre as diferentes abordagens, suas origens e seus propósitos, evidenciando as possiblidades de diálogo e de complementaridade. 


\subsection{AS CONTRIBUIC̣ÕES DA PSICODINÂMICA DO TRABALHO}

A inscrição da psicodinâmica do trabalho (PDT) no âmbito das ciências que estudam este tema, que é tão vasto e permeado por diversos campos de pensamento distintos se dá, como todos os outros, de modo peculiar e possui uma história específica. Uma das suas grandes contribuições é que, ao mesmo tempo em que há o desenvolvimento de um determinado tipo de conhecimento científico, isto é, o das relações subjetivas e intersubjetivas relacionadas com o trabalhar, há uma orientação indelével dirigida à ação. O conhecimento obtido é, então, fruto de uma reflexão que está inscrita também na possibilidade de transformação do trabalhar na ótica dos sujeitos.

Uma pesquisa em PDT seria constituída, em primeira instância, por uma reflexão coletiva que se expressa nos documentos produzidos com os pesquisadores, que se constituem um instrumento que serve também para colocar em diferentes espaços públicos aquilo que os grupos elaboraram com relação às vivências do seu trabalho. Os processos de transformação se dariam tanto pela elaboração feita naquele grupo, como pelo potencial que a circulação dos seus resultados, traria para ajudar na reflexão de outros e na indução de mudanças.

Ao se inscrever no âmbito da psique humana, a discussão da saúde mental relacionada ao trabalho é o ponto de ancoragem da PDT. Na sua origem há uma forte influência da psicanálise, um campo de conhecimento e, sobretudo de ação baseado na reflexão e na elaboração a ser desenvolvida pelos sujeitos que participam de um processo analítico. Este trabalho de elaboração é, de modo similar mas não idêntico, uma vez que a PDT está centrada no trabalhar. Através desses processos de elaboração, torna-se possível para os sujeitos que eles coloquem em evidência a sua vivência, assim como permite que sejam colocados em questão os mecanismos de defesa (SZNELWAR et al., 20I I).

No que diz respeito, aos temas centrais deste trabalho, a PDT permite uma reflexão bastante significativa uma que vez que os sujeitos ao se colocarem frente às questões que lhes tocam diretamente oriundas do seu trabalho, se confrontam com algo que é central em suas vidas. Ela propicia aos sujeitos uma reflexão comum sobre o protagonismo de cada um e, ainda o colocar em evidência o próprio protagonismo do trabalho nos processos de produção afeitos àquela profissão.

Como podemos situar a PDT, no âmbito das ciências? Para Uchida, Sznelwar e Lancman (20II), a questão da epistemologia da PDT poderia ser analisada, baseado em Monzani (s.d.), de modo similar àquele que este autor usa para a psicanálise, assim seria importante colocar em evidência a sua especificidade, o seu discurso e os critérios de validação, reforçando a ideia que não haveria um ideal unitário de ciência. 
As origens da psicodinâmica do trabalho se encontram nos debates feitos por psiquiatras franceses em meados do século XX, onde a questão da gênese das doenças mentais estaria em foco. As questões iniciais estavam relacionadas com a patologia mental; não é à toa que a disciplina detinha o nome, até a década de I990 de psicopatologia do trabalho, nome que reflete o posicionamento de Sivadon (1952) quando este autor discute a questão de uma possível origem das doenças mentais no trabalho. Assim como Le Guillant, seu contemporâneo, ele defendia a origem no social, como causa fundamental dessas patologias, por outro lado consideravam também o fato de o trabalho ter um amplo potencial terapêutico. Assim ao questionarem um possível papel patogênico do trabalho, e mantendo a ideia do seu potencial terapêutico, esses autores já permitem delinear os conceitos adotados e desenvolvidos mais recentemente por Dejours (I992), quando este afirma que não há neutralidade no trabalho, que este pode gerar o melhor e o pior no que diz respeito à saúde mental, assim como para a o desenvolvimento da cultura. Todavia convém explicitar que, nas suas origens, a psicopatologia do trabalho foi constituída a partir de um ponto de vista oposto ao da psicanálise, Para Uchida, Sznelwar, Lancman (20I I) Le Guillant seria adepto da sociogênese das patologias mentais se posicionava próximo da perspectiva defendida por Pavlov e em consonância com os preceitos do Partido Comunista Francês, ao qual estava afiliado. A psicanálise proposta por Freud era por eles considerada como uma ideologia burguesa e reacionária, como provavelmente seria a crítica à noção de protagonista, uma vez que esta proposta está centrada nos sujeitos, mesmo que o trabalhar sempre seja em um determinado coletivo e que não há subjetividade sem intersubjetividade.

Assim, na visão proposta por esses precursores da psicopatologia do trabalho o sujeito não era um tema, a ideia ventilada tinha mais a ver com uma visão de massa humana e não de indivíduos. Assim, a sua excelente contribuição ao descrever uma síndrome neurótica relacionada com o trabalho das telefonistas e dos mecanógrafos era tributária de um posicionamento mecanicista de causa e efeito, sem adentrar uma reflexão que relacionasse mais profundamente as questões de um sistema de trabalho definido a partir de uma perspectiva taylorista-fordista com o sofrimento patogênico, que teria sim causas ligadas à organização do trabalho, mas que seria relacionado com a psique dos sujeitos. Para Molinier (2006), a descrição feita por Le Guillant é rica e detalhada, mas a sua análise é empobrecida pela sua visão mecanicista, mesmo considerando a riqueza do material empírico que ele coletou.

Apesar da heteronomia na definição das tarefas, principalmente no caso da organização clássica, o trabalho não é exterior à pessoa, não é algo que lhe é conferido e que o sujeito deve apenas cumprir procedimentos, repetir gestos ou discorrer uma fala definida anteriormente. A ação do sujeito seria sempre 
construída por ele na sua atividade, portanto vivida e incorporada. Assim, a psicopatologia do trabalho, no seu início e que é ainda adotada por Dejours na década de I980 não permite a adoção desta proposta (DEJOURS, 2008). Isto é sanado pelo desenvolvimento posterior da disciplina, quando é proposta a mudança do nome da disciplina para o de psicodinâmica do trabalho, quando são adotados conceitos mais abrangentes sobre o trabalho, principalmente na relação dialética entre sofrimento e prazer.

Dejours afirma que no contexto anterior a sua base conceitual estaria bastante próxima de um posicionamento onde a organização do trabalho deveria ser considerada como algo de rígido e monolítico (DEJOURS, 2o I Ib). Neste momento ele não coloca em evidência as falhas que nela existem nem a questão da relação entre a organização real e prescrita do trabalho. Assim, os trabalhadores teriam frente a eles algo já definido, preexistente, fruto de um taylorismo bastante bem constituído. Este percurso pode ter sido uma primeira etapa, mesmo que aparentemente contraditória, para colocar em pauta uma visão mais próxima da perspectiva aberta pela psicanálise de Freud, uma vez que, a riqueza e a quantidade de questões e, mesmo de dúvidas suscitadas por este tipo de pensamento, não se coadunaria com uma visão rígida e finalizada do mundo e do ser humano. A adoção dos conceitos relacionados com as defesas psíquicas já é uma mostra que Dejours não considerava, já no início, que as respostas dadas por Le Guillant seriam satisfatórias e suficientes, principalmente no que diz respeito a um determinismo de causa e efeito na relação saúde - doença. A inspiração na psicanálise, como mostra a adoção desse conceito, já colocava em evidência que os trabalhadores não eram passivos frente aos constrangimentos organizacionais, uma vez que estes seriam capazes de se proteger, através de estratégias defensivas individuais e coletivas, mesmo que isto representasse uma possibilidade muito restrita de ação e que paradoxalmente não defenderia de fato a saúde mental, uma vez que pode indicar muito mais um processo alienante do que de emancipação.

Um outro tema tratado pelo autor em conjunto, tem a ver com o questão da profissão em si, quando são discutidos os temas do saber-fazer e das regras de ofício, abrindo uma outra vertente na disciplina, a da importância e o significado da profissão para o desenvolvimento dos sujeitos. A questão do protagonismo pode ser aqui considerada, uma vez que já é mostrada a importância do posicionamento de cada um para que um trabalho de qualidade seja feito e, também para que as suas atividades sejam desenvolvidas com prudência frente aos riscos existentes nas situações de trabalho em foco (CRU, I986).

Migrar da psicopatologia para a da psicodinâmica do trabalho permitiu sair de uma questão estritamente relacionada com o sofrimento para uma onde a estariam em evidência os mecanismos subjetivos e intersubjetivos da relação 
com o trabalho. Note-se que é à mesma época que as ideias neoliberais apregoam uma produção centrada na individualização em detrimento do coletivo; todavia trata-se de uma valorização aparente do indivíduo, mas há muito de reificação do sujeito por trás. Isto porque, ao mesmo tempo em que se apregoa que tudo depende do indivíduo, a produção pode existir sem ele, trata-se de uma peça descartável que, de modo semelhante aos modelos organizacionais pode ser facilmente trocada. A rotatividade é estimulada, mesmo nos escalões mais elevados da hierarquia, tornando as relações de trabalho mais friáveis (SENNETT, 2008).

Neste período, a questão da centralidade do trabalho, como um mediador entre o inconsciente e a sociedade, é defendida por Dejours de modo explícito, trazendo uma novos desafios conceituais para a PDT. O trabalhador não estaria "assujeitado" aos constrangimentos organizacionais de modo que lhe sobrariam apenas os mecanismos de defesa para se defender, isto é, não estaria mais em uma situação de se adaptar ou não ao trabalho, mas teria através da sua atividade, a possibilidade de subverter esta ordem, de transformar o sofrimento em prazer, com um potencial de transformação do real, de agir no mundo, em cooperação com outros.

Aqui podemos encontrar um outro ponto de ancoragem para a proposta do conceito de protagonista, uma vez que os processos de cooperação, da mobilização da inteligência astuciosa, da intersubjetividade, e da importância daquilo que há de coletivo no trabalho são questões que mostram a importância do trabalho para que a produção ocorra, isto é reforçando as duas propostas desta tese.

Um das armadilhas preparadas pelos ideais da organização propostos a partir do desenvolvimento da corrente neoliberal está relacionada a algo que já foi rapidamente tratado neste texto mas que precisa ser um pouco mais aprofundado. Todos buscam, de alguma maneira ser reconhecidos pelo que fazem. Fazer bem feito e, em acordo com as regras da profissão seria, em uma primeira instância, um desejo se considerarmos que o esforço de cada um resultaria em algo de útil e belo. Portanto, ao defendermos a necessidade de um processo de desenvolvimento continuo da cultura, aquilo que cada um faz passaria por um crivo, um julgamento, onde seriam consideradas questões ligadas à ética de uma maneira geral e, de modo mais específico, às regras de uma determinada profissão.

O sujeito em busca de reconhecimento deseja ser avaliado. Isto já acontece desde o princípio do desenvolvimento de cada um, a aprovação materna, em primeiro lugar, é fundamental para o desenvolvimento da criança, é assim que ela aprende os valores e, constitui seu universo simbólico, onde aquilo que faz suscita no outro uma ação que lhe causa prazer, seja um carinho, um sorriso, algo que lhe permita reconhecer que está fazendo algo que engendra simpatia. 
Considera-se que no trabalho, há algo semelhante. A necessidade de saber se aquilo que fez, o resultado do seu esforço, foi bem avaliado é considerada como uma fundamental para o reforço dos processos ligados ao reforço da identidade do sujeito. Ao propor que cada um seja avaliado, a partir dos mais variados sistemas de avaliação, focados sobretudo nos resultados obtidos, as organizações nada mais estariam fazendo do que responder a esta necessidade básica. Todavia é justamente aí que um grande risco para a saúde mental do sujeito se instaura, uma vez que lhe deixa fragilizado frente a uma possível injustiça. Isto não significa que todos os sistemas sejam nefastos, mas há uma grande margem para que as ações de quem avalia sejam coalhadas de arbitrariedades. Principalmente porque, há todo um esforço para, ao individualizar o desempenho nas empresas, quebrar o que há de coletivo na produção. Com isso a capacidade de resistência dos sujeitos fica comprometida.

O reforço da individualidade, paradoxalmente, ajuda a fragilizar e, por vezes, a criar as condições propícias para o desenvolvimento de sofrimento patogênico nas situações de trabalho. Os sistemas de avaliação que se baseiam quase que exclusivamente no cumprimento de metas, definidas a partir de determinados critérios que desconsideram as dificuldades encontradas pelos trabalhadores e que também negam a importância da cooperação e da solidariedade para que a produção saia a contento, tem sido criticados pela PDT, uma vez que estariam na base de certas práticas que levam à precarização das relações de trabalho e à quebra da solidariedade entre colegas (DEJOURS, 2003).

Neste cenário se instala também um debate sobre a questão do assédio moral no trabalho. Para Heloani (2007), trata-se de um velho problema e de uma discussão mais recente. Esta discussão ganha o espaço público a partir de final do século XX justamente no momento onde essas práticas organizacionais ganham corpo, onde as formas de solidariedade perdem espaço para esta ideologia que releva o indivíduo, justamente para fragiliza-lo. Para esse autor, este cenário é coalhado de problemas, tais como a contradição entre a necessidade de cooperação e a competição desenfreada; o fato de que a "hipercompetividade" reforça a violência perversa e que, influenciadas por uma "subliteratura organizacional”, as empresas se tornam anoréxicas. Assim o assédio seria algo intencional na busca desqualificar o outro; um processo de perversão moral, e que, apesar de ter como alvo pessoas mais fragilizadas devido às relações de produção, à divisão sexual do trabalho, ao fato de já terem algum adoecimento, pode se disseminar e se democratizar.

Note-se que a questão do protagonista se coloca de modo bastante significativo com relação a essas questões, uma vez que, ao se colocar no centro da cena, com todo o esforço e os riscos que há de se expor, o sujeito busca algum tipo de reconhecimento. Naquilo que Freud considerava como atividades com forte 
poder sublimatório, como as dos artistas, esta questão aparece como evidente. No ponto de vista da PDT, em qualquer profissão, haveria um forte potencial sublimatório. Todavia este potencial poderia ser solapado pela maneira como os processos de produção são organizados e divididos, definindo, em muitas situações de trabalho, tarefas com pouco conteúdo, com pouco potencial para o desenvolvimento de atividades subjetivantes (BÖHLE; MILKAU, I998).

Em casos extremos, encontraríamos as tentativas de suicídio e a sua concretização. Há estudos que mostram uma relação entre certos modos de organizar o trabalho, sobretudo quando se busca aprofundar a individualização, através dos mecanismos de avaliação, de premiação, em detrimento das atividades mais coletivas e as mortes por autoagressão. (DEJOURS e BËGUE, 20I0). Este tipo de ação, típica do desespero, da desolação, de alguém que já não encontra saídas possíveis para os impasses que vive no seu trabalho se colocados na perspectiva do protagonista, poderia ser considerada como um gesto quase que de um egoísmo extremo, onde a dramaturgia da vida atingiria o seu ápice. O extremo do individualismo poderia então ser enxergado como um caminho para a destruição do sujeito. Todavia mesmo nesta situação, o ato é endereçado a outrem, sempre é um gesto que traz alguma mensagem, muitas vezes explícita em algum documento deixado pelo sujeito, muitas vezes através da simbologia ligada ao modo e ao local onde foi feito; nos casos de suicídio relacionado com o trabalho, esses são, de forma praticamente hegemônica, realizados nos próprios locais de trabalho ou próximos a eles. Quando deixam algum documento, a questão da maneira como este é organizado, como são os sistemas de avaliação de desempenho e a sensação de solidão e de desolação, são evidenciados (DEJOURS, I999b e 20I Id). Este contexto reforça a questão dialética para a sobre a relação entre sofrimento e prazer para a PDT. Temas tais como suicídio relacionado ao trabalho, as patologias da sobrecarga, as patologias da solidão e da servidão, a banalização de certas práticas organizacionais de injustiça social, que poderíamos considerar como manifestações do universo da psicopatologia mostram a importância da inserção de questões mais amplas, envolvendo uma discussão mais política sobre o trabalho em si.

Para a PDT a possibilidade de transformação do sofrimento em prazer está nos seus principais fundamentos, assim o sofrimento não seria necessariamente patogênico, se houver a possibilidade de, através da sua atividade, o sujeito consiga realizar os seus objetivos e ter o seu esforço reconhecido. Isto não seria exclusivo das atividades de trabalho, qualquer atividade humana resultaria de um esforço, do dar de si, do se colocar à prova, de vencer a resistência do real, assim o sofrimento faria parte dos processos humanos de aprendizagem (BIRAN, I954/I955). Na proposta de Maine de Biran, o pensamento teria origem na incapacidade inicial de realizar algo. O fato de, por exemplo, não conseguir alcançar um objeto, não ter como realizar os seus desejos por não saber 
andar, estaria na gênese do pensamento da criança, uma vez que para dar conta daquilo que ainda não consegue, ele precisará desenvolver alguma estratégia. Para sair do registro do desprazer seria necessário criar, se esforçar, tentar, não obter sucesso até que consiga realizar os seus intentos. Este tipo de definição de sofrimento não é a tradicional, uma vez que este conceito está mais relacionado com algo de negativo e que perdura; no caso presente partimos da noção de sofrimento como algo relacionado com o penar, com aquilo que é árduo para o sujeito, mas que visa um determinado resultado e que ao alcança-lo teria um efeito transformador, subvertendo a experiência. Esta perspectiva se inscreve no universo da racionalidade pathica, aquela que diz respeito ao vivido pelo sujeito, o da experiência, do desenvolvimento do saber-fazer. Assim, haveria algo de criativo no sofrimento não patogênico, a práxis e a poiesis seriam permeadas pelo esforço, pelo sofrimento que teria sentido para o sujeito, principalmente porque guarda a possibilidade de subversão em prazer.

Em acordo com os preceitos da PDT, a subversão do sofrimento, ou ainda a sua transformação, em prazer seria inerente a todas atividades de trabalho. Todavia para que isto seja possível, é necessário que haja condições que são propiciadas pela maneira como o trabalho é organizado, evitando que esta possibilidade seja bloqueada. Aqui cabe uma menção à noção de bloqueio, questão trabalhada por CLOT (I999) quando este autor propõe o conceito de atividade impedida. O impedimento estaria relacionado a problemas de saúde como as LER/DORT (SZNELWAR, 2003), (SZNELWAR; MASCIA; BOUYER, 2006). Impedidos de fazer, de se manifestar, de dizer o que pensam, os sujeitos sofreriam consequências significativas no âmbito da economia psicossomática.

O fato de não poder se expressar no trabalho de acordo com os seus desejos e sua maneira de ser engendraria um conflito entre o sujeito e seus desejos e aquilo que lhe é demandado pelas prescrições pertencentes ao universo da tarefa. Um reforço do impedimento de se expressar, daquilo do que não pode ser dito, pode inclusive ter consequências para o próprio desenvolvimento do pensamento, ao não poder se expressar, estaria o sujeito, de alguma forma também impedido de pensar. Será que a possibilidade que restaria aos sujeitos estaria na expressão sob a forma da somatização (LER/DORT, problemas vocais), de distúrbios na economia psíquica como as síndromes depressivas, ou ainda através da passagem ao ato sob a forma de violência com relação aos outros e aos equipamentos, ou até de processos de auto agressão. As estatísticas epidemiológicas, reportando uma maior incidência de diferentes problemas de saúde no trabalho, sejam no âmbito da expressão como patologias da economia do corpo ou da psique são preocupantes (PREVIDÊNCIA SOCIAL, 2008).

Para ajudar a compreender esses fenômenos, partindo de um debate com a psicanálise tradicional, Dejours (200I) propõe o conceito de terceira tópica. 
Esta é oriunda de uma interlocução com Laplanche e sua obra $(1987,2007)$ e traz um enriquecimento substantivo no que diz respeito à compreensão de fenômenos psíquicos, pois incorpora a existência de um inconsciente amencial ou proscrito ao lado do inconsciente recalcado (DEJOURS, 20I 2a). Esta proposta permite explicar a emergência de quadros psicossomáticos, comportamentos psicóticos (como a passagem ao ato) e que não seriam compreendidos a partir da segunda tópica fundada por Freud. Se por um lado, a proposta da terceira tópica enriquece os postulados freudianos, por outro permite discutir e debater as propostas das escolas psicossomáticas, como a etiologia do pensamento operatório que surge das ações para lidar com o trabalho repetitivo, ou seja, a auto-aceleração do trabalho fenômeno já detectado e não explicado pela ergonomia.

Assim, a proposta de terceira tópica pode ajudar a explicar de modo mais contundente a relação entre a saúde mental e o trabalho. A proposta de distinguir dois inconscientes, um que seria recalcado, portanto fruto de um processo simbolização e, um outro amencial, que não passou por esse processo, que não foi elaborado. Isto permite diferenciar o que há na experiência dos sujeitos e que pode, de alguma forma, emergir através de ideias e de pensamentos que ao serem melhor elaborados poderão ajudar a construir soluções para os problemas (inconsciente recalcado) diferenciando daquilo que está recoberto de um manto espesso e escuro e que se expressa sob a forma de processos auto-destrutivos evidenciados por doenças no corpo ou ainda por situações de passagem ao ato (inconsciente amencial). Ao se fortalecer certas propostas de organização do trabalho que favorecem de modo extremado uma racionalidade instrumental que refute uma reflexão e um respeito maior a aspectos éticos da produção, numa perspectiva axiológica, haveria um reforço da parte amencial da psique. Para tentar se defender, o sujeito muito clivado, desenvolve comportamentos permeados de explicações muito racionais que, ao invés de expressarem um amplo processo de elaboração, exprime uma certa pobreza, fruto da falta de elaboração e reflexão. Dentre esses comportamentos, podemos citar aqueles de tipo obsessivo-compulsivo descritos por Le Guillant (2006) a partir dos estudos realizados junto a seus colegas, comportamentos esses também encontrados por nós junto a trabalhadores de teleatendimento (SZNELWAR e MASSETTI, 2002).

Um outro conceito tratado pela PDT, e que estaria em aparente contradição com aquilo que foi explicitado nos parágrafos anteriores, seria relativo ao consentimento. Para Dejours (20I 2b), não haveria um sujeito passivo que, simplesmente se submete aos constrangimentos da organização do trabalho. Conforme já descrito anteriormente com relação às defesas psíquicas, esta questão é mais complicada, uma vez que, de alguma maneira o sujeito convive com o desprazer, com o risco, enfim, para viver se defende. Neste caso, conforme La 
Boétie, o conceito de servidão voluntária seria útil, assim a restrição à liberdade, teria algum tipo de compensação, algum ganho secundário, não visível à uma leitura mais simples (LA BOETIE, 2002). Dejours utiliza este conceito quando propõe uma discussão sobre a banalização de certas práticas e, mesmo ao se interrogar sobre o fato das pessoas aceitarem trabalhar em situações que seriam desprovidas de conteúdo e sob forte constrangimento organizacional. Haveria portanto uma discussão importante sobre a relação entre o ser impedido de e a perspectiva da aceitação de uma determinada imposição. Até que ponto os sujeitos consentem, quais processos psíquicos de defesa ou de compensação estariam envolvidos? Será que, muitos sujeitos, de modo defensivo, acreditariam que o trabalho seria apenas um meio para conseguirem determinados objetivos materiais e sociais, aceitando assim uma determinada organização, perpetuando certas práticas condenáveis, enfim, vivendo uma certa ilusão de que passariam ilesos, sem sequelas, por certas experiências?

Os trabalhos em PDT, mostram que não seria o caso. Toda atividade humana não poderia ser considerada como algo que simplesmente acontece ou aconteceu, o sujeito está engajado por inteiro, mesmo que os processos de clivagem possam dificultar ou até impedir um trabalho de elaboração da experiência. A ação humana é dotada de uma intenção, o agir é sempre expressivo, carregado de sentimentos em consonância com aspectos mais profundos da sua personalidade (DEJOURS, 200I). Portanto, o dar de si para realizar algo não é banal, a sua vivência sempre deixa traços, assim uma ação transformadora, seria a de permitir que o sujeito refletisse, elaborasse a sua experiência de trabalho.

Para a PDT não há neutralidade no trabalho, toda experiência de trabalho está modulada por processos que podem ou não favorecer o desenvolvimento da inteligência, da cooperação, da solidariedade que, de alguma maneira serviriam ou não para favorecer os processos de sublimação e da realização de si. Nada é dado como uma estrutura pré-existente, como algo monolítico, o trabalho se constitui por experiências desenvolvidas em cenários que são dinâmicos e que são modulados pelas ações e decisões de diferentes atores (MAGGI, 2006).

O trabalhar seria muito mais que um movimento, que um processo cognitivo, que um funcionamento do corpo. Seria uma ação do sujeito que engaja seu corpo, seu pensamento, sua psique, sem que se possa separá-las como processos independentes. Qualquer tentativa de separação teria apenas fins didáticos, só poderia ser proposta na perspectiva de distingui-las, mas considerar que estão todas relacionadas seria um conceito importante e que aproxima o ponto de vista aqui adotado da Teoria da Complexidade, isto é, o de relação, o do tecer em conjunto (MORIN, I990).

Tratar o tema do protagonista no transcurso da evolução da PDT pode ser feito de diferentes maneiras, uma vez que o sujeito que vivenciaria o trabalho 
entendido sob a ótica da sobre-determinação, usada no início do desenvolvimento da disciplina, seria o mesmo que teria a possibilidade de trilhar um caminho em direção à emancipação, presente nas propostas mais recentes. Não podemos afirmar que haja uma situação a ser entendida como algo absoluto e definitivo, há falhas e contradições que podem ser analisadas e desveladas em qualquer situação de trabalho. Da mesma forma que não podemos afirmar que haveria um sujeito totalmente "sobre-determinado", não há alguém completamente emancipado. Nessas falhas, nessas contradições e sobretudo nessas possibilidades que se constitui o protagonista, sejam elas de cunho biológico, psíquico ou social / organizacional. A ideia da sobre-determinação proposta por Freud traz uma noção de camadas, isto é, que sempre haveria algo por trás que poderia ajudar a explicar os determinantes de certos pensamentos e comportamentos, as interpretações de um fenômeno não se restringiriam a um único plano (LAPLANCHE; PONTALIS, I976). Para Dejours (20I 2a), os sujeitos nas situações de trabalho, viveriam sob a égide de uma relação entre a psique e o biológico, e em enfrentamento com as injunções externas, oriundas das relações de trabalho e expressas nos constrangimentos das tarefas.

Com respeito à psique, a importância para o sujeito de desenvolver um trabalho a partir das exigências oriundas das pulsões, permite um entendimento maior sobre a relação entre o psíquico e o somático, entre a instauração do sentido em relação às exigências de trabalho oriundas das pulsões (DEJOURS, 2009, 20IId). A relação entre a centralidade do sexual, proposta por Freud e a centralidade do trabalho, proposta por Dejours, ganha forma, quando este autor propõe a tese que o trabalho é o mediador principal entre o inconsciente e o social como dito anteriormente (DEJOURS, I999a).

Apesar de não tratar diretamente do trabalho ordinário Freud usa em muitas situações o termo Arbeit, para designar o trabalho do eu sobre as pulsões, fator fundamental para o desenvolvimento do sujeito, isto é, o destino das pulsões dependeria da elaboração a ser feita por ele (HANNS, I999). Seria aí que se constituiriam os processos da sublimação, nos quais a energia pulsional poderia ser direcionada para algum tipo de atividade outra que não a estritamente relacionada com o sexual (UCHIDA; SZNELWAR; LANCMAN, 20II). Os processos de elaboração psíquica seriam os responsáveis pela criação da alma (DEJOURS, 20I2a).

Relacionar o que há de mais íntimo no sujeito, oriundo do mundo biológico, como as pulsões, consideradas como fonte, como energia impulsionadora para as ações do sujeito e, o mundo externo, é algo que já existe na obra de Freud, principalmente ao considerarmos que para ele o sujeito não se constitui por si próprio mas na relação com o outro, isto é, no âmbito da intersubjetividade ajudaria bastante no desenvolvimento do conceito do protagonismo. Estar no 
centro da cena da sua existência, como já dito anteriormente, não significa estar sozinho, uma vez que é sempre em relação ao outro que estamos agindo, mesmo que o outro não esteja em nossa frente, ele está sempre presente.

Assim o trabalho que o sujeito faz ao tratar daquilo que emerge do seu íntimo está duplamente direcionado, tanto para dar um destino às suas pulsões, como, em relação àquilo que lhe é exterior, agir de modo compatível e coerente com as expectativas dos outros, enfim, da sociedade. Assim, um reforço para que o sujeito continue desenvolvendo uma criação voltada para o mundo, estaria relacionado como o reconhecimento do outro. Vários conceitos utilizados na PDT, como aqueles para discutir a questão da avaliação do trabalho, teriam origem nesta discussão; ao trabalhar o sujeito colocaria em cena aquilo que já lhe é próprio em relação com aquilo que o mundo traz como exigência. Seria, portanto, o confronto de duas exigências que se constituem mutuamente, isto é, de duas resistências derivadas, por um lado, das capacidades e limites de cada um e que podem ser aprimoradas, isto é, da sua própria psique e, por outro lado, as derivadas das exigências do mundo real, que resistem e colocam à prova o sujeito. Enfim trabalhar seria sempre em duplo sentido, um em direção aos outros e outro em direção a si mesmo.

A possibilidade de construir saídas e conseguir construir algo que, no final teria um grande potencial sublimatório, permite ao sujeito ultrapassar o obstáculo que o mundo opõe ao seu domínio e, concomitantemente permite o desenvolvimento do próprio com aquilo que há de progresso para a constituição e organização da sua economia psíquica. Lembrando que a psique deve ser entendida em sua plenitude, também na sua corporeidade. Esta metapsicologia do corpo é uma das contribuições de Dejours para as discussões da psicanálise e para a psicossomática e pode ser relacionada com as questões colocadas anteriormente relativas à necessidade de elaboração que o sujeito tem a partir das suas necessidades mais primárias de sobrevivência que exigem uma ação que, no princípio, o sujeito não é ainda capaz. Aqui podemos entender melhor porque Dejours propõe uma interlocução com Maine de Biran para explicar como a resistência que o sujeito encontra no seu corpo ao tentar experimentar o mundo, este "fato primitivo" de alguma maneira constituiria o próprio pensamento. Este processo constituiria uma apercepção imediata de si e que poderia se relacionar com o conceito de constituição do eu proposto por Freud (DEJOURS, 2OI $2^{\mathrm{a}}$ ) (UCHIDA; SZNELWAR; LANCMAN, 2OII).

Todavia Dejours, vai mais além com relação a o que propôs Maine de Biran, uma vez que para ele, a questão não está reduzida a uma relação do eu com o eu, numa relação solipsista. O mundo teria uma importância na mediação de tudo isso, a relação com o outro é fundamental para os processos de constituição e de transformação do eu. 
A possibilidade de obtê-lo, assim como o reconhecimento do outro seriam fundamentais com relação à saúde mental, reforçando o fato de que este processo não é definitivo, terminado, a saúde advém das possibilidades de e não de algo definido e determinado. Isto implica que, ao se tratar de um processo dinâmico, de uma busca constante (DEJOURS, I985), e de uma questão intersubjetiva é importante que entendamos como um processo e que, a própria noção da saúde está relacionada com as confirmações que obtemos no âmbito do trabalho, através do olhar do outro (MOLINIER, 2003). Na perspectiva do protagonista, seria o de dar continuidade a uma história singular, onde o sujeito estaria sempre em busca de algo e que este processo seria duplamente modulado, tanto pelo que há de mais íntimo como o da sua relação com o mundo.

Da mesma maneira que a ergonomia e, em respeito às suas próprias origens na psicanálise, a PDT não é um domínio do conhecimento humano voltado para a constatação de fatos ligados à psique humana no trabalho. Trata-se de um campo onde, os processos de conhecimento estão claramente relacionados com os processos de transformação. De uma certa forma, é nos processos de transformação que se cria o conhecimento. Portanto não haveria uma dissociação entre teoria, método e ação (DEJOURS, 20 I Ia). Se ao cabo dos processos de constituição do sujeito, estaria a perspectiva da emancipação e do desenvolvimento da cultura, as ações propostas na PDT devem estar em consonância com esses objetivos. As possibilidades para que o espectro de ação dos sujeitos e dos coletivos sejam ampliadas e fortalecidas estão relacionadas, em um primeiro lugar, a um processo de elaboração das experiências onde cada um se posiciona em um determinado coletivo que, ao mesmo tempo aí se constitui. A partir das falas individuais, que ganham o espaço público comum a eles, onde ao explicitar a sua experiência, o sujeito desenvolve um trabalho sobre si e, também propicia condições para que os outros também o façam, se constrói ou se reconstrói a possibilidade de uma elaboração comum, de construção de um sentido que, estaria relacionado com os fundamentos daquela profissão. Esta reconstrução do sentido, teria uma importância fundamental para uma re-apropriação do poder de agir. Haveria, portanto, um potencial de transformação da realidade, oriundo de um processo de elaboração individual e coletiva, isto é, através de um processo de transformação de si.

As ações em PDT estariam, por princípio, alinhadas com esta perspectiva de emancipação. Uma busca constante de coerência deve fazer parte das preocupações daqueles que se propõem a agir no campo para que se construa, a partir da recuperação da vivência dos sujeitos no seu trabalhar, processos de transformação mais efetivos. Este posicionamento busca responder a uma demanda social que não se restringe ao diagnóstico e à denúncia no que diz respeito aos problemas de saúde, em especial os de saúde mental ligados ao trabalho, mas 
também de reverter uma tendência de banalização das formas de organização do trabalho que têm se mostrado nefastas para a saúde pública, e que têm legitimado formas de dominação que buscam "esterilizar" ou "pasteurizar" as paixões e os desejos dos sujeitos (DEJOURS, I999b). Recuperar ou afirmar o papel do sujeito como protagonista do seu trabalho e o do protagonismo do trabalho na produção seria parte dessa discussão.

Apesar do fato de partirmos do pressuposto que o processo de emancipação seja oriundo de um desejo mais profundo dos sujeitos, não deveria ter uma resposta do tipo sim ou não, uma vez que a realidade do trabalho e das suas relações é muito mais complicada, ou seja, o próprio fato de que, há bloqueios significativos com relação às possibilidades de expressão dos trabalhadores nas mais diversas organizações.

A relação dependência / emancipação está sempre presente na vida humana, uma vez que não existe autonomia no sentido absoluto da palavra, mas sim processos que apontam para esta direção. Esta relação dialética, aparentemente contraditória, está presente em todas as relações, assim os processos de ação em PDT não podem ser considerados como um caminho único que vai levar à emancipação dos trabalhadores, mesmo que este seja o objetivo primordial.

Para reforçar os objetivos da PDT recolocar em evidência que a dinâmica sofrimento-prazer no trabalho é útil. A partir de uma inspiração no campo da antropologia psicanalítica, mas também da teoria dos princípios, o sofrimento não deve ser considerado como um mal em si, mas sim parte de um processo. A própria construção do sujeito passa por um processo de desafio do real, que resiste aos desejos, que nos confronta, que exige. Isto nos faz sofrer, mas ao obtermos o resultado desejado, nos ajuda, pois nos permite um enriquecimento enquanto sujeitos. Haveria sim uma diferença significativa, com relação ao sofrimento patogênico que nos impede, não permite que trilhemos um processo de construção de si. Ressalte-se que esses impedimentos são tanto de ordem externa aos sujeitos como interna. A ideia de quantificar esse sofrimento, de classificar situações de sofrimento em oposição a situações de prazer, de buscar avaliar se situações de sofrimento preponderam sobre as de prazer, ou qualquer outra busca que retire o caráter dinâmico dessa relação não pode ser formulada como uma ação em PDT. Assim, não é o caso de manter a questão do sofrimento e prazer como polos opostos de uma mesma ontologia. Isto seria, no mínimo, se manter na perspectiva mecanicista / positivista da relação saúde / doença, pois a questão é muito mais complicada e não se trata de uma linha balizadora que permitiria ao sujeito se posicionar para entender onde ele está situado. As dinâmicas entre sofrimento e prazer mostram que, para o sujeito, a passagem pelo primeiro é fundamental para que consiga atingir os seus objetivos, todavia não se trata de uma etapa vencida definitivamente e que faria parte 
de algo vivido no passado, esta vivência estará sempre presente, mesmo que num registro inconsciente.

Ao confrontar-se com o real do trabalho e com o real do seu inconsciente, o sujeito se põe à prova, prova esta que tem um enorme potencial subjetivo se essas relações não estiverem bloqueadas, seja pela maneira como são definidas a partir da organização do trabalho, seja pela própria dinâmica estruturante da sua psique. Estamos, então, adotando uma perspectiva em que os sujeitos, a partir do seu trabalho, podem trilhar um caminho que aponta para um processo de emancipação, onde seja possível um distanciamento da alienação.

Antes de terminar esta discussão inicial sobre a psicodinâmica do trabalho vale ressaltar o tema da avaliação com relação ao papel de protagonista. Este assunto, em parte tratado anteriormente, é fundamental na constituição e na afirmação do sujeito ao longo de sua vida. Não se constitui um sujeito sem que ele seja avaliado, julgado e incentivado por aqueles como os quais se relaciona. Isto desde a mais tenra idade. Assim a questão da avaliação é central e o fato de que nos métodos mais prevalentes nas empresas, o foco está na avaliação individual do desempenho, isto tem acarretado muitos problemas e desafios para a saúde mental dos trabalhadores. Não se trata de uma questão localizada afeita a alguma realidade específica, como o mostram diferentes estudos na área de saúde mental, mas de práticas disseminadas e que tem sido discutidas de modo mais aprofundado em encontros científicos.

Para Sznelwar, Uchida e Mascia (2008), as ações desenvolvidas em ergonomia e em psicodinâmica do trabalho poderiam ser um preambulo daquilo que poderia fazer parte dos processos de avaliação, uma vez que elas revelam questões fundamentais do trabalho real e que não são tratadas nos métodos utilizados nas empresas. Assim, dispositivos a serem criados poderiam se constituir em verdadeiros espaços de palavra.

O debate centrado nesta questão permite compreender os riscos ligados a essas práticas desenvolvidas nas empresas. Os desenvolvimentos mais recentes no campo da PDT trazem a baila o quão este tipo de abordagem individual de desempenho não corresponde ao real do trabalho e como esta pode ser nefasta para a saúde mental, pois coloca o sujeito sempre em situação de fragilidade, confrontado sempre consigo mesmo e com o seu interlocutor, que tem poder hierárquico. As questões coletivas, as dificuldades para produzir, a necessidade de resolver outras questões que podem interferir nos resultados são tratadas marginalmente, o que está no centro é a produção do indivíduo e aspectos do seu comportamento que são identificados pelos seus interlocutores. Há casos em que os sujeitos se sentem questionados em aspectos que não tem nada a ver com a questão do trabalho e o fato de não poderem contar com o respaldo de colegas os coloca, muitas vezes, em xeque. Isto deixa pouca margem para agir, em geral, 
leva a uma aceitação, a um aprofundamento de processos de submissão e, de um modo mais defensivo, de alienação.

A discussão pública sobre esses temas, nas empresas, em instituições públicas, em entidades de representação, em encontros científicos e, também em processos amplos de divulgação em diferentes mídias pode ser muito importante para que se reverta essas tendências de submissão e alienação. A busca de não valorizar e de até combater aquilo que há de coletivo na produção tem como um das consequências a deterioração do viver junto. Isto contribui para o desenvolvimento de patologias do trabalho, como as patologias de sobrecarga, da solidão e da desolação. Não é à toa que a questão dos suicídios ligados ao trabalho se tornou um dos temas de preocupação na área.

A recuperação daquilo que há de coletivo no trabalho e da recuperação de caminhos de maior cooperação e solidariedade pode ser uma alternativa, todavia isto só é possível se houver mudanças efetivas na maneira de se organizar e de se avaliar o trabalho, garantindo que haja conteúdo significativo para aqueles que trabalham, isto é, que suas ações façam sentido e que permitam trilhar caminhos que visem a construção da saúde, para a realização de si e para a emancipação através do trabalho.

Tudo isso não integra um campo exclusivo do conhecimento, como o da PDT, mas de diferentes áreas próximas, que se ocupam do trabalho. O debate com as ciências da engenharia e da gestão, com a ergonomia, como outras áreas que cuidam da saúde, da psicologia, das ciências sociais pode ser muito profícuo para o entendimento dessa problemática, inclusive visando o desenvolvimento de processos de mudança. Isto reforça que não se trata de algo a ser tratado por um tipo de "especialistas", mas por pessoas preocupadas com uma ação transformadora no mundo do trabalho. 
